\title{
IgA and FcaRI: Versatile Players in Homeostasis, Infection, and Autoimmunity
}

This article was published in the following Dove Press journal:

ImmunoTargets and Therapy

\section{Melissa Maria Johanna \\ van Gool id 1,2 \\ Marjolein van Egmond ${ }^{1-3}$ \\ 'Department of Molecular Cell Biology and Immunology, Amsterdam UMC, Amsterdam, Vrije Universiteit Amsterdam, Amsterdam, Netherlands; ${ }^{2}$ Amsterdam institute for Infection and Immunity, Amsterdam UMC, Amsterdam, Netherlands; ${ }^{3}$ Department of Surgery, Amsterdam UMC, Vrije Universiteit \\ Amsterdam, Amsterdam, Netherlands}

Video abstract

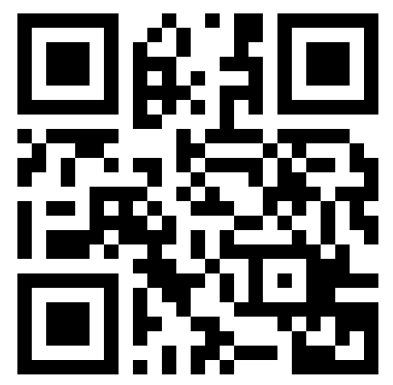

Point your SmartPhone at the code above. If you have a $Q R$ code reader the video abstract will appear. Or use: https://youtu.be/xlijXy5W0xA
Correspondence: Marjolein van Egmond Tel +31204448080

Email m.vanegmond@amsterdamumc.nl
Abstract: Mucosal surfaces constitute the frontiers of the body and are the biggest barriers of our body for the outside world. Immunoglobulin A (IgA) is the most abundant antibody class present at these sites. It passively contributes to mucosal homeostasis via immune exclusion maintaining a tight balance between tolerating commensals and providing protection against pathogens. Once pathogens have succeeded in invading the epithelial barriers, IgA has an active role in host-pathogen defense by activating myeloid cells through divers receptors, including its Fc receptor, Fc $\alpha$ RI (CD89). To evade elimination, several pathogens secrete proteins that interfere with either IgA neutralization or FcaRI-mediated immune responses, emphasizing the importance of IgA-FcaRI interactions in preventing infection. Depending on the IgA form, either anti- or pro-inflammatory responses can be induced. Moreover, the presence of excessive IgA immune complexes can result in continuous FcaRImediated activation of myeloid cells, potentially leading to severe tissue damage. On the one hand, enhancing pathogen-specific mucosal and systemic IgA by vaccination may increase protective immunity against infectious diseases. On the other hand, interfering with the IgAFc $\alpha$ RI axis by monovalent targeting or blocking Fc $\alpha$ RI may resolve IgA-induced inflammation and tissue damage. This review describes the multifaceted role of FcaRI as immune regulator between anti- and pro-inflammatory responses of $\operatorname{IgA}$, and addresses potential novel therapeutic strategies that target FcaRI in disease.

Keywords: neutrophil, CD89, mucosa, infection, inflammation, autoimmunity

\section{Introduction}

The immune system is a central player in protecting the host against infectious diseases. Synergy between both innate and adaptive immunity is essential to induce effective immune responses against invading microbes. Immunoglobulins are major players of the adaptive immune response, and contribute to both immune defense and maintaining homeostasis. ${ }^{1}$ Based on structure and effector functions, five major immunoglobulin isotypes can be distinguished, ie, $\operatorname{IgM}, \operatorname{IgD}, \operatorname{IgG}, \operatorname{IgA}$, and $\operatorname{IgE}$ that differ in the Fc tail. Immunoglobulins can mediate neutralization, thereby preventing invasion of pathogens or toxins. Additionally, immunoglobulins constitute a bridge between pathogens and the innate immune system facilitating complement activation as well as inducing effector cell functions by immune cells. ${ }^{2,3}$ Binding of the immunoglobulin Fc tail to their cognate Fc receptor, which can be distinguished in receptors for $\operatorname{IgG}(\mathrm{Fc} \gamma \mathrm{Rs}), \operatorname{IgE}(\mathrm{Fc \varepsilon RI}), \operatorname{IgA}(\mathrm{Fc} \alpha \mathrm{RI}), \operatorname{IgM}(\mathrm{Fc} \mu \mathrm{R})$, and $\operatorname{IgA} / \operatorname{IgM}$ $(\mathrm{Fc} \alpha / \mu \mathrm{R})$, induces cellular activation. ${ }^{4}$

Mucosal surfaces like the respiratory-, urogenital- and gastrointestinal tracts are continuously exposed to environmental factors and therefore considered as the

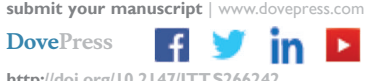

htp:/1doi.org 10.21474105266242
ImmunoTargets and Therapy 2020:9 35I-372 
frontiers of the body. Tolerating harmless antigens while providing protection against pathogens is a challenging feature of mucosal immunity. IgA is the predominant immunoglobulin at mucosal surfaces and in external secretions. It contributes to mucosal homeostasis by neutralizing toxins and viruses, preventing colonization and invasion of pathogenic bacteria, clearing unwanted particles, and promoting sampling of luminal antigens. ${ }^{5,6}$ In serum, IgA is the second most abundant antibody after IgG. Nonetheless, the exact functions of serum IgA are relatively unexplored and ill understood. ${ }^{7}$

Binding of IgA to its Fc receptor, Fc $\alpha$ RI, can initiate either pro- or anti-inflammatory responses. It was demonstrated that interaction of monomeric serum $\operatorname{IgA}$ with Fc $\alpha$ RI induces inhibitory signals (Figure 1A). ${ }^{8}$ As such, it is suggested that IgA and FcoRI contribute to homeostatic conditions. ${ }^{9}$ By contrast, IgA immune complexes (eg, IgA-opsonized bacteria) induce pro-inflammatory responses by cross-linking of Fc $\alpha \mathrm{RI}$, which is important in controlling infections (Figure 1B). ${ }^{10,11}$ The presence of excessive IgA immune complexes or IgA-opsonized bacteria can however lead to uncontrolled and disproportionate FcaRI-mediated immune cell activation, resulting into severe tissue damage as observed during chronic inflammation and autoimmunity. ${ }^{12}$ Increased serum IgA levels or IgA autoantibodies have been reported in multiple diseases including rheumatoid arthritis, IgA nephropathy, IgA vasculitis, dermatitis herpetiformis, celiac disease, inflammatory bowel disease, Sjögren's syndrome, ankylosing spondylitis, alcoholic liver cirrhosis, and acquired immunodeficiency syndrome. ${ }^{13-20}$ The role of Fc $\alpha$ RImediated inflammation in pathology is still poorly understood. This review summarizes the different functions of FcaRI and its ligand IgA during homeostasis, infection, chronic inflammation, or autoimmunity, and addresses the possibilities of targeting FcaRI for therapeutic strategies.

\section{FcaRI and IgA: The Basics}

\section{FcaRI Structure and Expression}

Human FcaRI is a member of the Fc receptor immunoglobulin superfamily. Nevertheless, Fc $\alpha$ RI has some distinct features compared to other Fc receptors. The FcaRI gene
A

\section{IgG immune complex}

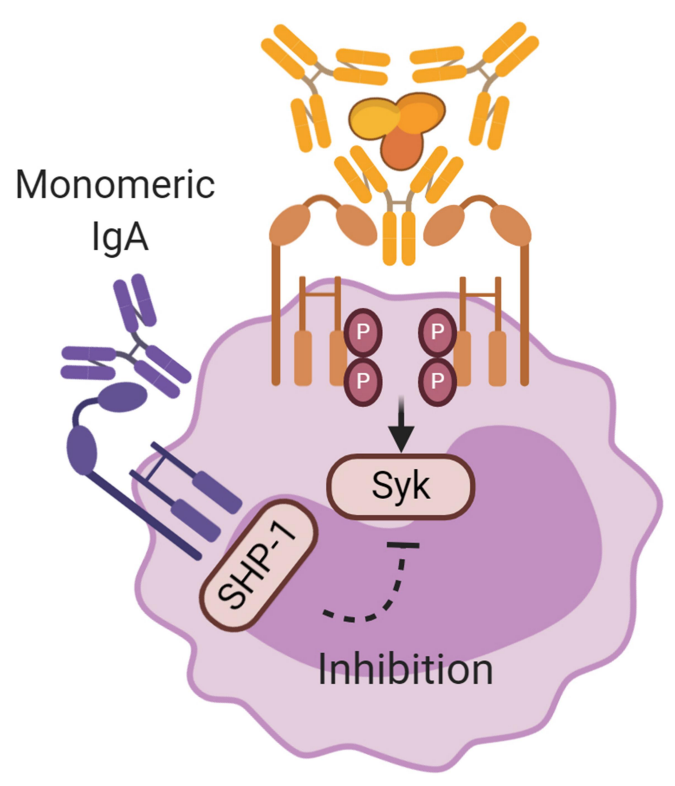

B

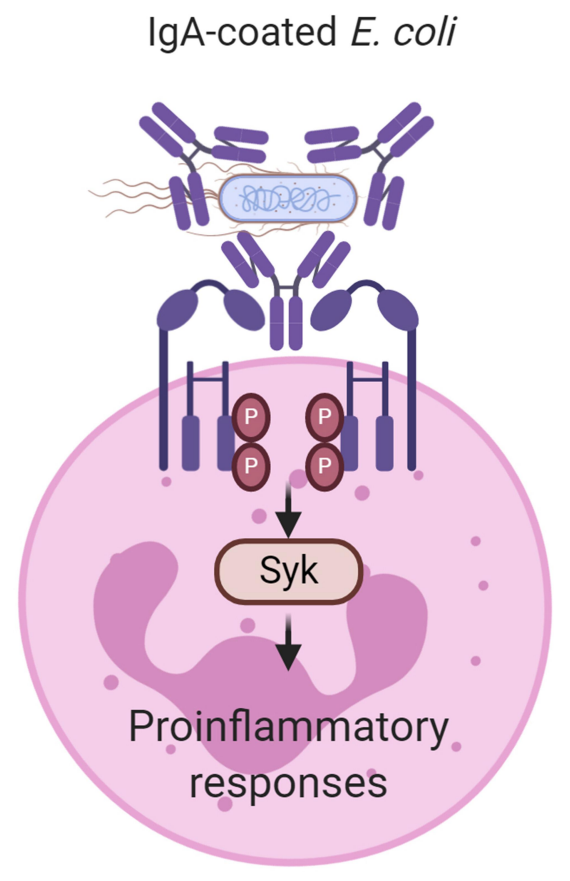

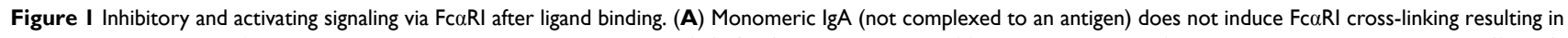
partial phosphorylation of immunoreceptor tyrosine-based activation motifs (ITAMs) and recruitment of Src homology region 2 domain-containing phosphatase-I (SHP-I). This results in inhibition of ITAM signaling, and impairs phosphorylation of spleen tyrosine kinase (Syk), LAT and ERK, which is initiated through signaling via other activating Fc receptors (like lgG-mediated Fc $\gamma$ receptor activation). The exact binding of free dlgA to Fc $\alpha$ RI, and concomitant signaling, has not yet been resolved. (B) IgA immune complexes (eg IgA-coated Escherichia coli) induce cross-linking of FcaRI, resulting in ITAM phosphorylation of the associated FcR $\gamma$-chain. Phosphorylated ITAMs subsequently function as a docking site for signaling molecules such as Syk. Syk plays an essential role in initiating signaling pathways, including the Ras/Raf/MEK/MAPK pathway. Activation of signaling pathways results in pro-inflammatory cellular functions such as phagocytosis, antibody-dependent cellular cytotoxicity, respiratory burst, degranulation, antigen presentation, and release of NETS, cytokines and inflammatory mediators. Created with BioRender.com. 
(FCAR) is located on chromosome 19 (19q13.4) within the leukocyte receptor cluster (LRC), whereas other human FcR genes are located on chromosome 1. ${ }^{21,22}$ LRC also encodes leukocyte Ig-like receptors and natural killer cell immunoglobulin-like receptors. The amino acid (aa) sequence of Fc $\alpha$ RI resembles LRC encoded receptors more closely than other $\mathrm{Fc}$ receptors. ${ }^{23}$ FCAR consists of five exons that encode for the leader peptide ( $\mathrm{S} 1 ; 34$ base pairs (bp), and S2; $36 \mathrm{bp}$ ), two extracellular Ig-like domains (EC1 and EC2; 291 bp and 288 bp) and a combined transmembrane and cytoplasmic region (TM/ C; $215 \mathrm{bp}){ }^{24}$ FCAR encodes a transmembrane receptor, which consists of two extracellular domains (EC1 and EC2; each 206 aa) that are folded with an angle of approximately $90^{\circ}$ to each other. ${ }^{25}$ The transmembrane region (19 aa) is crucial for association with FcR $\gamma$ chain, ${ }^{26}$ and Fc $\alpha$ RI has a short cytoplasmic tail (41 aa). Fc $\alpha R I$ is expressed on the surface of myeloid cells, including neutrophils, eosinophils, monocytes, macrophages, Kupffer cells, and human platelets. ${ }^{12,27,28}$ Additionally, low FcaRI levels were observed on in vitro cultured immature monocyte-derived dendritic cells (DCs) as well as on monocyte-derived $\mathrm{CD} 103^{+} \mathrm{DCs}$, which resemble human epithelial interstitial-type DCs. ${ }^{29,30}$ The molecular weight of FcaRI ranges between 50 and 75 kilodalton (kDa) due to differences in $\mathrm{N}$ glycosylation, with the exception of FcaRI on eosinophils, which is between 70 and $100 \mathrm{kDa}^{31}$ Orthologues of human FcaRI have been identified in several monkey species, horses, cattle, hamsters, gerbils, and rats, but not in mice due to a gene translocation. ${ }^{32,33}$

FcaRI is constitutively expressed and independent of its ligand. Expression can be modulated by several mediators, such as lipopolysaccharide (LPS), chemoattractants, cytokines, or adapter protein binding to the intracellular domain of Fc $\alpha$ RI. ${ }^{33,34}$ Upregulation of FcaRI on neutrophils occurs rapidly by either transport from an intracellular pool to the cell surface or via de novo synthesis and is induced by $\mathrm{N}$-formylmethionyl-leucyl-phenylalanine (fMLP), interleukin (IL)-8, tumor necrosis factor-alpha (TNF- $\alpha$ ), LPS, and granulocyte-macrophage colony-stimulating factor (GMCSF). ${ }^{35-38}$ On monocytes and monocyte-like cell lines FcaRI expression was enhanced by calcitriol, LPS, TNF$\alpha$, GM-CSF, and IL- $1 \beta{ }^{39,40}$ Downregulation occurs in the presence of transforming growth factor- $\beta$ (TGF- $\beta$ ), interferon- $\gamma$ (IFN- $\gamma$ ), or by ligand binding due to Fc $\alpha$ RI aggregation and internalization. ${ }^{41,42}$

\section{IgA Binding to FcaRI}

Humans express two closely related IgA subclasses, ie, IgA1 and IgA2, whereas most mammals, except for rabbits and certain primates, express only a single IgA subclass that resembles IgA2. ${ }^{43-45}$ In serum, IgA1 is the predominant subclass with an IgA1:IgA2 ratio of 9:1, while $\operatorname{IgA} 2$ is mainly found in the colon. In other mucosal tissues, IgA1 and IgA2 are more evenly distributed. IgA1 and IgA2 differ in their hinge region and number of glycosylation sites. ${ }^{46}$ IgA1 contains a hinge region that is 13 amino acids longer compared to IgA2, which results in enhanced antigen recognition capacity but also in increased susceptibility for proteolytic cleavage by bacterial proteases. ${ }^{47}$ Furthermore, IgA1 contains three to six O-linked glycans in the hinge region, while IgA2 is devoid of O-linked glycosylation. ${ }^{48}$ O-linked glycans of IgA1 in external secretions can interact with bacterial adhesion molecules, contributing to mucosal homeostasis. ${ }^{49}$ Altered O-linked glycosylation can cause IgA1 conformational changes resulting in increased immune complex formation, which is a key pathogenic factor in diseases like IgA nephropathy. ${ }^{50}$

In humans, $\operatorname{Ig} \mathrm{A}$ is expressed in three different forms: ie, monomeric $\operatorname{Ig} \mathrm{A}$, dimeric $\operatorname{Ig} \mathrm{A}(\mathrm{d} \operatorname{Ig} \mathrm{A})$, and secretory $\operatorname{Ig} \mathrm{A}$ ( $\operatorname{SIgA}$ ). Serum IgA is mostly monomeric and produced by plasma cells in the bone marrow, spleen, and lymph nodes. By contrast, IgA at mucosal sites is predominantly dimeric and produced by local plasma cells in the lamina propria. ${ }^{51,52}$ Dimeric $\operatorname{IgA}(\mathrm{dIgA})$ is composed of two monomers that are linked tail-to-tail with a joining (J-) chain via Cys471-mediated disulfide bonds forming a boomerang-like structure. ${ }^{53}$ It is transported across the epithelium by binding to the polymeric Ig receptor (pIgR), which is expressed on the basolateral membrane of epithelial cells. ${ }^{53,54}$ At the luminal side, pIgR is cleaved and a part of this receptor, referred to as secretory component (SC), remains attached to dIgA by binding both Fc-tails and J-chain across the $\sim 50^{\circ}$ gap between the two monomers, thereby forming SIgA (Figure 2A). ${ }^{55,56}$

All (iso)forms of IgA are ligands for Fc $\alpha$ RI, although binding of SIgA to Fc $\alpha$ RI is (partially) hampered due to steric hindrance of SC.$^{57}$ Furthermore, binding of SIgA requires the presence of macrophage-1 antigen (Mac-1, CD11b/CD18). ${ }^{58}$ Monomeric IgA and dIgA bind with moderate affinity $\left(\mathrm{K}_{\mathrm{a}}=\right.$ $10^{6} \mathrm{M}^{-1}$ ), whereas IgA immune complexes bind with higher avidity and induce crosslinking of Fc $\alpha \mathrm{RI} .{ }^{33}$ Optimal binding of IgA immune complexes occurs with five to six molecules of IgA per complex. ${ }^{59}$ In particular residues Pro440-Phe443 and 
A

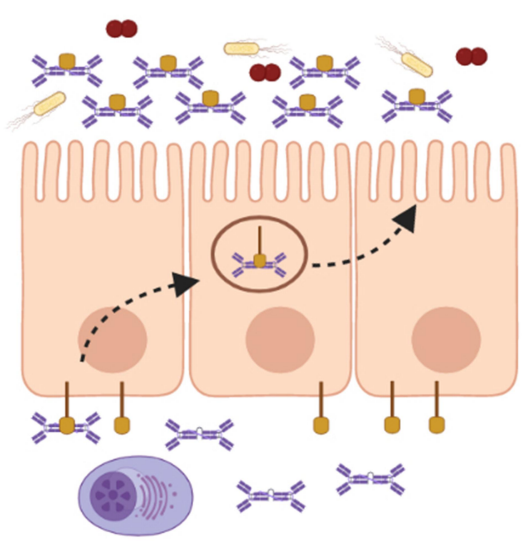

B

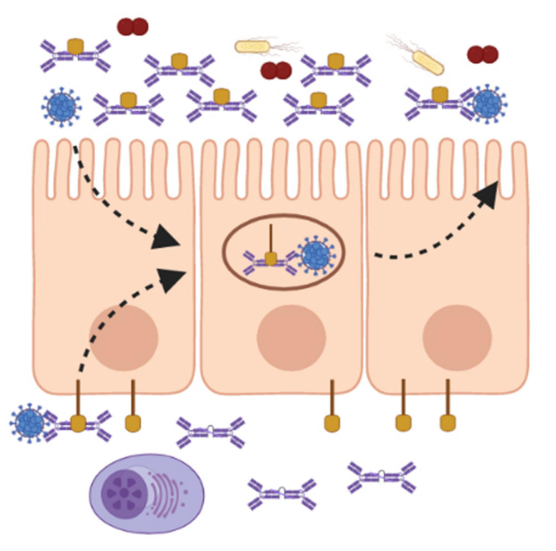

C

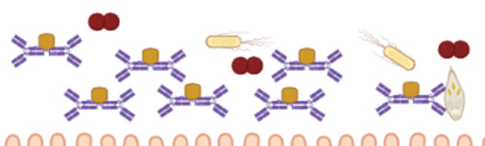

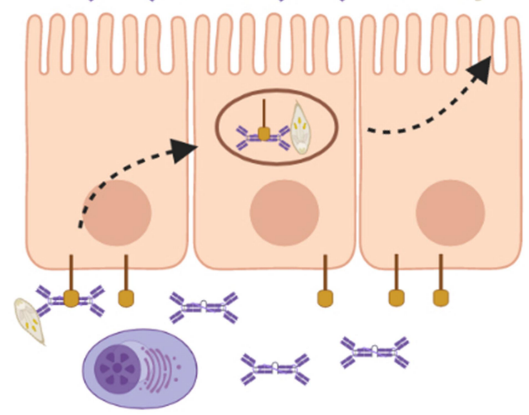

E
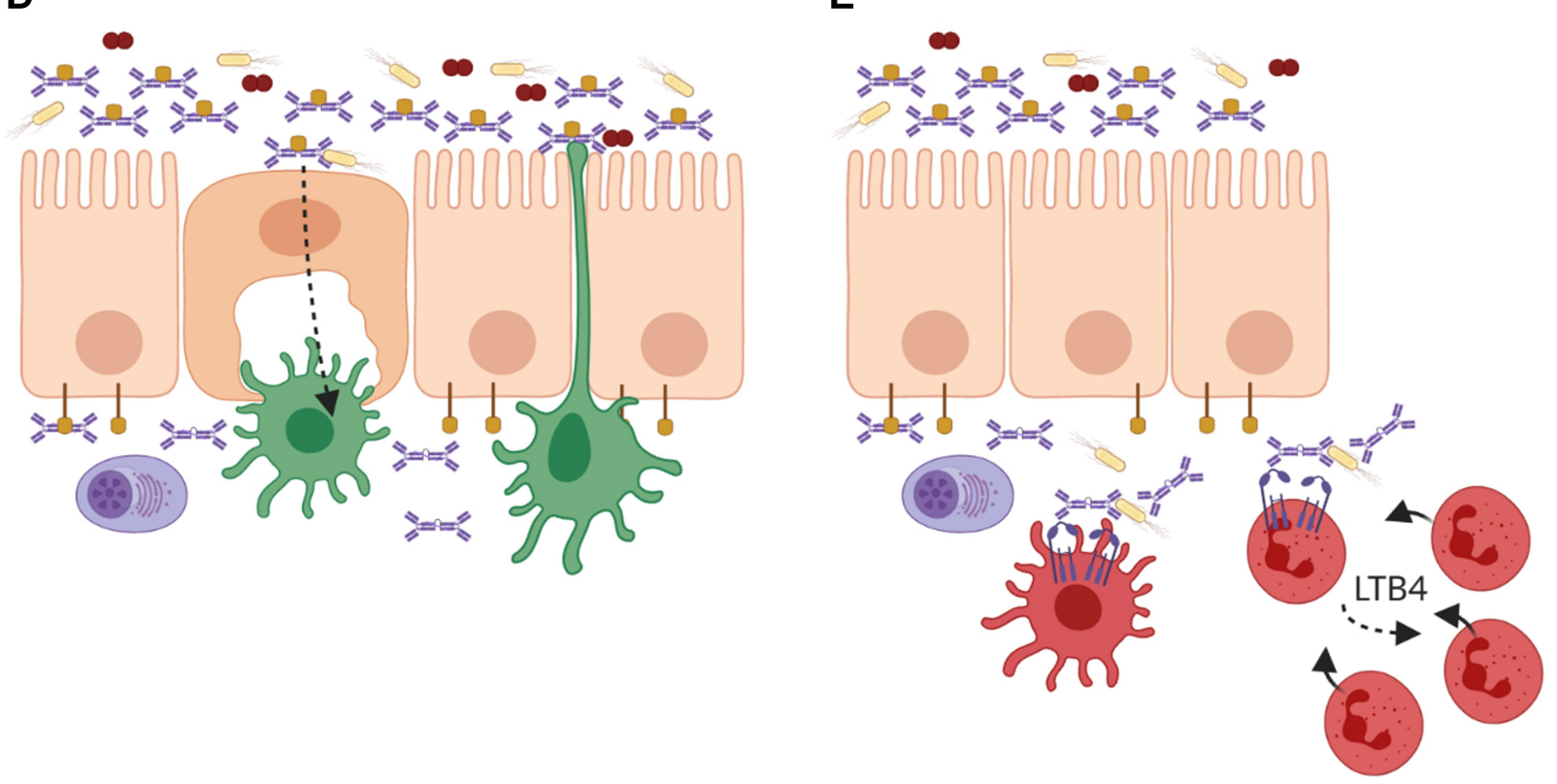

Figure 2 Roles of $\lg A$ and $F c \alpha R I$ in homeostasis and infection at mucosal sites. (A) Local plasma cells in the lamina propria produce dimeric lgA (dlgA), which is transported across the epithelium into luminal secretions by binding to the polymeric lg receptor (plgR). At the luminal side it is released as secretory lgA (SlgA) where it can neutralize pathogens and toxins. (B) On route of being secreted, dlgA can intercept viruses, which have infected epithelial cells and redirect them into the lumen. (C) Invading pathogens and antigens in the lamina propria are opsonized by dlgA and transported back into the lumen. (D) Microbes that are opsonized with SlgA are shuttled via microfold (M) cells to dendritic cells (DCs) in Peyer's patches for sampling. Additionally, DCs can extend dendrites through the epithelial layer for sampling of the luminal content. (E) During infection, dlgA-opsonized pathogens are taken up by FcaRI-expressing DCs, and presented to T cells. Additionally, phagocytosis of dlgA-opsonized pathogens by neutrophils results in the release of leukotriene B4 (LTB4), which mediates the chemotaxis of more neutrophils to the site of infection, thereby functioning as a self-contained positive feedback loop of immune cell recruitment to clear invading pathogens. Created with BioRender.com.

Leu257-Leu258 in the FcaRI EC1 are essential for IgA binding. ${ }^{60}$ Monomeric IgA binds to FcaRI via its $\mathrm{C} \alpha 2$ and Ca3 domains in a 2:1 stoichiometry (one IgA molecule binds simultaneously two FcaRI molecules). ${ }^{25,61}$ This is in contrast with other Fc receptors since FceRI and FcyRIII bind their ligands in EC2 in a 1:1 stoichiometry. ${ }^{62-65}$ In theory, dIgA can bind four Fc $\alpha$ RI due to its multiplied binding sites, although this may not be possible due to steric hindrance. As such, it still remains unclear how dIgA exactly binds to FcaRI. ${ }^{66}$ It has been described that pentraxins, including acute phase C reactive protein $(\mathrm{CRP})$ and serum amyloid $\mathrm{P}(\mathrm{SAP})$, compete for FcaRI binding since these proteins recognize a similar binding site on FcaRI as IgA. ${ }^{67}$ Mutations in FcaRI outside the IgA-binding site enhanced pentraxin binding to Fc $\alpha$ RI with 2-fold whereas IgA binding was unaffected, suggesting additional binding sites for pentraxins. ${ }^{67}$ 
FcaRI harbors six N-glycosylation sites which affect the binding affinity of IgA to Fc $\alpha$ RI. Altered glycosylation of FcaRI due to a specific mutation (Asn58 to Glu58) resulted in a nearly 2-fold increased binding of IgA. Furthermore, removal of sialic acids increased IgA binding with nearly 4 -fold. ${ }^{68} \mathrm{IgA}$ binding to Fc $\alpha$ RI can also be regulated by intracellular signals that are modulated by cytokine stimulation of cells (also referred to as insideout signaling), independently of FcaRI expression levels. ${ }^{69}$ Increased binding of IgA to FcaRI in transfected cells, eosinophils, and monocytes was reported in the presence of cytokines like GM-CSF, IL-4, and IL-5 without increasing FcaRI expression levels on the cell surface. ${ }^{70,71}$

\section{FcaRI Signaling and Cellular Activation}

FcaRI does not contain any known signaling motifs. In order to initiate effector functions, FcaRI associates with the FcR $\gamma$-chain subunit, which contains an immunoreceptor tyrosine-based activation motif (ITAM) in its intracellular domain. ${ }^{26}$ In the transmembrane regions, the positively charged arginine on position 209 (R209) in FcoRI associates with the negatively charged aspartic acid 11 (D11) in FcR $\gamma$-chain. ${ }^{72}$ The FcR $\gamma$-chain ITAMs contain conserved paired tyrosines and leucines in a consensus sequence $\left(\mathrm{YxxL}_{\mathrm{x}} \mathrm{x}_{7-12}-\mathrm{YxxL}\right)$. Binding of monomeric serum IgA (not complexed with an antigen) leads to partial phosphorylation of FcR $\gamma$-chain and involves extracellular signal-related kinases (ERK)-dependent recruitment of tyrosine phosphatase Src homology region 2 domain-containing phosphatase-1 (SHP-1) to sphingolipid-cholesterol-rich membrane domains. ${ }^{8}$ Cytoplasmic clusters referred to as inhibisomes hamper spleen tyrosine kinase (Syk), linker for activation of T cells (LAT), and ERK phosphorylation, thereby inhibiting pro-inflammatory responses that are induced by other activating Fc receptors. ${ }^{73}$ This process is referred to as inhibitory ITAM (ITAMi) signaling (Figure 1A), which may represent an anti-inflammatory mechanism to prevent uncontrolled release of inflammatory responses (see also below).

By contrast, binding of IgA immune complexes to FcaRI induces cross-linking of FcaRI, resulting in proinflammatory responses (Figure 1B). After crosslinking, tyrosines in ITAMs are phosphorylated by the Src kinase Fyn, forming docking sites for other tyrosine kinases, including Syk. ${ }^{74-76}$ Syk plays an essential role in the activation of several proteins, including phosphoinositide 3-kinase (PI3-K), phospholipase $\mathrm{C} \gamma$ (PLC $\gamma$ ), and $\mathrm{Src}$ homology and collagen adaptor protein (Shc). These proteins initiate multiple signaling pathways, including the Ras/Raf/MEK/MAPK pathway and the Rho family GTPase pathway. These pathways are also interconnected and can therefore modulate each other. ${ }^{74-76}$ Syk additionally induces the release of second messengers such as calcium and diacylglycerol. ${ }^{77}$ Activation of signaling pathways results in remodeling of the actin cytoskeleton and activation of transcription factors such as nuclear factor kappa-light-chain-enhancer of activated B cells (NF-kb), ultimately leading to cellular activation (for detailed description of FcaRI signaling, see Aleyd et al). ${ }^{10}$

Depending on the cell type, FcaRI activation can result in phagocytosis, degranulation, superoxide generation, release of neutrophil extracellular traps (NETs), antibody-dependent cellular cytotoxicity (ADCC), release of cytokines and chemokines, or antigen presentation. ${ }^{12}$ It has been shown that phagocytosis of IgA-coated particles by neutrophils induces increased reactive oxygen species (ROS) production and NET release, which can contribute to pathogen elimination. ${ }^{78}$ Additionally, cross-linking of FcaRI by serum or $\operatorname{dIgA}$ initiates the release of the chemoattractant leukotriene B4 (LTB4) with concomitant neutrophil recruitment. ${ }^{79}$ SIgA was able to induce respiratory burst in neutrophils, although less efficiently compared to serum IgA. It did not induce efficient uptake of pathogens by either neutrophils or Kupffer cells. ${ }^{27,80}$ Cross-linking of Fc $\alpha$ RI by IgA immune complexes on immature DCs resulted in antigen presentation through the major histocompatibility complex class II pathway, DC maturation, and production of IL$10 .{ }^{81-83}$ Since IL-10, together with TGF- $\beta$, mediates IgA isotype switching in B cells, Fc $\alpha$ RI-positive DCs are described to be important for the induction of IgA by B cells in secondary lymphoid organs. ${ }^{84}$ Additionally, crosslinking of FcaRI on in vitro generated human $\mathrm{CD}_{103}{ }^{+}$DCs (resembling human epithelial interstitial-type DCs) resulted in the release of pro-inflammatory cytokines like TNF- $\alpha$, IL$1 \beta$, IL-6, and IL-23. ${ }^{29}$ SIgA was internalized by DCs as well, albeit through carbohydrate-recognizing receptors instead of FcaRI, which did not result in DC maturation. ${ }^{85}$

\section{FcaRI and IgA: Homeostasis Immune Exclusion and Immune Regulation}

In mucosal areas like the respiratory-, urogenital-, and gastrointestinal tracts, SIgA plays a key role in keeping a tight balance between tolerating commensals and harmless antigens while providing protection against harmful pathogens. ${ }^{86}$ 
Due to its multiple binding sites, SIgA opsonizes bacteria with high avidity thereby interfering with bacterial motility and inducing bacterial agglutination. This can block the entrance of bacteria into the mucosal epithelium. ${ }^{87}$ Additionally, bacterial products like enzymes and toxins are also neutralized by $\operatorname{SIgA}{ }^{88}$ This process, referred to as immune exclusion, is the main described function of SIgA and prevents local and systemic infection (Figure 2A). ${ }^{86}$ Not only bacteria but also viruses can be neutralized by mucosal IgA. On route to be secreted, dIgA has the ability to intercept and disarm viruses, which have infected epithelial cells and redirect them back into the lumen (Figure 2B). ${ }^{12}$ Similarly, pathogens that have invaded the epithelial barrier into the lamina propria are likely opsonized by $\operatorname{dIgA}$ and transported back into the lumen (Figure 2C). It has been shown that $\operatorname{IgA}$ neutralized several viruses, including sendai, influenza, rota, measles, and human immunodeficiency virus 1 (HIV-1). ${ }^{89-94}$ Additionally, SIgA plays an important role in shaping and diversifying the gut microbiome. ${ }^{95}$ Mice lacking IgA showed reduced overall microbial diversity resulting in altered bacterial composition, increased bacterial translocation, and ultimately intestinal inflammation. ${ }^{96-98}$ Similarly, humans with defective mucosal IgA responses, such as Selective IgAdeficiency (SIgAd), showed modest but significant changes in the gut microbiota composition. ${ }^{99}$ High-microbiota binding as well as cross-species reactivity of $\operatorname{IgA}$ was shown to promote host-microbiota symbiosis, hereby maintaining intestinal mucosal integrity and homeostasis. ${ }^{100-102}$ Yet, the functional effects of $\operatorname{IgA}$ binding to microbiota fitness or physiology remain unclear. IgA production is also microbiota-dependent, as germ-free showed diminished IgA titers compared to specific-pathogen-free mice. ${ }^{103,104} \operatorname{IgA-}$ producing plasma cells were absent in most tissues of germfree mice and significantly reduced in the small intestine, reflecting the importance of microbiota in initiating humoral responses. $^{101}$

SIgA immune complexes (eg, IgA-opsonized bacteria) can be transported from the lumen into the lamina propria via the transferrin receptor 1 (TfR1 or CD71) on epithelial cells or via Dectin-1 on microfold cells ( $\mathrm{M}$ cells) (Figure 2D). ${ }^{105,106}$ Reverse transcytosis of SIgA is important for the uptake and delivery of antigens from the intestinal lumen to gut-associated lymphoid tissues (GALTs) influencing immune responses. ${ }^{106,107}$ SIgA immune complexes are taken up by DCs through interaction with Dendritic CellSpecific Intercellular adhesion molecule-3-Grabbing Nonintegrin (DC-SIGN). ${ }^{85}$
In the circulation, serum IgA has likely an immunomodulatory role through inhibitory signals via ITAMi signaling (Figure 1A). It was shown that monovalent targeting of FcaRI resulted in the inhibition of oxidative burst activity, chemotaxis and IgG-mediated phagocytosis and cytokine production. ${ }^{108-111}$ Furthermore, in transgenic mice that express human FcoRI on myeloid cells, IgEmediated asthma was prevented by the binding of soluble IgA to Fc $\alpha$ RI, which inhibited FceRI-induced degranulation of mast cells. ${ }^{8}$ ITAMi signaling by Fc $\alpha$ RI is therefore suggested to play a role in maintaining homeostasis and protection against enhanced Fc $\gamma$ receptor- or FceRImediated activation during inflammatory diseases and allergies. $^{9}$

\section{Early-Life Immunity}

SIgA is the predominant antibody in human colostrum and described to protect offspring from infection when the neonatal immune system is still immature. ${ }^{112,113} \operatorname{IgA}$ and IgM are not able to cross the placenta through the neonatal Fc receptor (FcRn) and can therefore only be provided through maternal milk. ${ }^{114}$ Breastfeeding is important for the development of the neonatal intestinal microbiota and can protect infants from infectious diseases. ${ }^{114-116}$ Studies in mice have shown that colostrum is the only source of SIgA in the first weeks of life since it takes up to approximately 4 weeks for the neonatal intestine to be populated by IgA-secreting B cells. ${ }^{116,117}$ In humans, mucosal IgA in the fetal intestine is absent or rarely present until 10 days after birth. ${ }^{118}$ IgA-producing B cells become pre-dominant 1-2 months after birth and increase in number until 6 to 11 months of age. ${ }^{119}$ The highest concentration of SIgA is found in colostrum; however, prolonged breastfeeding resulted in increased IgA in maternal milk as well. ${ }^{120,121}$ Although the opsonic activity of SIgA is poor, early studies demonstrated that SIgA initiated macrophage phagocytosis and neutrophil respiratory burst. ${ }^{122}$ After antigen interaction, SIgA undergoes conformational changes, which enhanced the binding of SIgA immune complexes to FcaRI. ${ }^{123}$ In addition to immunoglobulins, maternal milk also facilitates the transfer of leukocytes. IgAinduced cellular effector functions may therefore contribute to early immunity against pathogens in newborns. It has been demonstrated that the majority of leukocytes present in maternal milk have a similar phenotype to blood cells, although leukocyte subsets are present in different frequencies. Myeloid precursors, neutrophils, and immature granulocytes are the main identified cells 
present in colostrum. ${ }^{124}$ Colostral neutrophils were able to phagocytose IgA-opsonized bacteria although this did not result in significant bacterial-killing and release of superoxide anion. This is likely due to FcaRI expression without $\gamma$ subunit association. ${ }^{125}$ The exact contribution of FcaRI-mediated cellular responses initiated by SIgA or leukocytes in maternal milk remains incompletely understood.

\section{FcaRI and IgA: Infection}

The production of $\operatorname{IgA}$, with a synthesis rate of $66 \mathrm{mg} / \mathrm{kg}$, exceeds that of all other antibodies combined supporting its importance in host-pathogen defense. ${ }^{12}$ Pathogen-specific IgA is found at mucosal surfaces and in circulation during several infectious diseases, while the exact function of $\operatorname{Ig} \mathrm{A}$ remains unclear. ${ }^{6,11}$ Passive immunity (via neutralization) as well as immune activating properties of $\operatorname{IgA}$ have been described for infections in the respiratory- and reproductive tracts such as Mycobacterium tuberculosis (Mtb), HIV-1, and more recently severe acute respiratory syndrome coronavirus 2 (SARS-CoV-2) infections. ${ }^{126-128}$

\section{Passive Immunity}

Respiratory infections often occur via inhalation of airborne droplets containing pathogens or via direct contact with respiratory secretions. ${ }^{129,130}$ The nasopharyngeal mucosa is furthermore a natural reservoir for several pathogens like Streptococcus pneumoniae (S. pneumoniae) and Neisseria meningitides (N. meningitides). ${ }^{131}$ In individuals who lack protective antibody titers, infections can occur causing various pathologies like pneumonia, meningitis, bacteremia, and sepsis. ${ }^{132,133}$ In mice, SIgA against $M t b$ or $S$. pneumoniae has been associated with protection against tuberculosis (TB) or pneumococcal disease respectively. ${ }^{134,135}$ The neutralizing capacities of IgA are not only described for bacteria since IgA against HIV-1 or rotavirus was able to neutralize either virus. Monomeric IgA1 or dIgA2 against envelope proteins (Env) of HIV-1 showed neutralizing activity in vitro. ${ }^{136}$ Moreover, mucosally applied Env-specific dIgA1 and dIgA2 protected rhesus macaques against an intrarectal challenge with simian-human immunodeficiency virus (SHIV). ${ }^{137,138} \operatorname{IgA}$ against rotavirus (RV-IgA) neutralized both virus in solution and virus that had bound to epithelial cells in vitro. ${ }^{139}$ Furthermore, it was shown that RV-IgA was produced in all rotavirus animal models (horse, cow, sheep, gnotobiotic piglet, rat, rabbit, and mouse) which correlated with clearance of infection and protective immunity. ${ }^{140-142}$
Generation of specific IgA in coronavirus disease 2019 (COVID-19) was described as well. ${ }^{143-146}$ It was suggested that SIgA antibodies against SARS-CoV-2 were able to neutralize the spike protein or nucleocapsid protein thereby providing protective mucosal immunity. ${ }^{147}$ It is unknown whether serum IgA anti-SARS-CoV-2 antibodies contribute to protection against COVID-19. On the one hand, it was demonstrated that severe COVID-19 illness was significantly associated with increased total serum $\operatorname{IgA}$ but not with total serum IgG levels. ${ }^{148}$ Furthermore, IgA levels correlated with disease score in critically ill patients. ${ }^{149}$ On the other hand, the presence of IgA and IgG antibodies against SARS-CoV-2 spike protein subunit 1 (S1) showed an inverse correlation with viral load. Additionally, enhanced titers of specific anti-S1 IgA in serum correlated with significant increased survival in COVID-19 patients 28 days post intensive care unit admission. ${ }^{150}$ Passive antibody therapy using convalescent plasma from recovered COVID-19 patients resulted in a reduction in viral load and better disease outcomes, most notably in less severely ill COVID-19 patients. $^{151-153}$ Nonetheless, since IgAspecific SARS-CoV-2 neutralizing antibodies were not determined in convalescent plasma that was transferred to COVID-19 patients, the exact contribution of IgA neutralizing antibodies in COVID-19 remains unknown. ${ }^{154-156}$ Longitudinal investigation of potentially protective functions of mucosal and systemic IgA is needed to determine their role in COVID-19.

\section{Active Immunity}

Although few FcaRI-positive cells are observed in mucosal areas in homeostatic conditions, Fc $\alpha$ RI-positive neutrophils are the first cells that are recruited after infection. ${ }^{79,157}$ Once pathogens have successfully invaded the epithelial barrier, they can become opsonized by $\operatorname{dIgA}$ in the lamina propria. It was shown that dIgA induced efficient phagocytosis by neutrophils. ${ }^{80}$ As such, a pro-inflammatory role for dIgA in eliminating infiltrating pathogens was proposed. ${ }^{33}$ Enhanced phagocytosis of Escherichia coli, Streptococcus pneumonia, Staphylococcus aureus, Porphyromonas gingivalis, Candida albicans, Bordetella pertussis, and Neisseria meningitides by neutrophils after targeting FcaRI has been demonstrated in vitro. ${ }^{27,79,80,158-161}$ Specific IgA antibodies against meningococcal capsular polysaccharides were shown to induce moderate phagocytosis by neutrophils but initiated respiratory burst more potently than IgG. ${ }^{80}$ Crosslinking of Fc $\alpha$ RI on neutrophils furthermore results in the release of LTB4, which is a potent neutrophil 
chemoattractant, and additionally mediates the migration of monocytes and monocyte-derived DCs. ${ }^{79,162,163}$ LTB4 release after neutrophil activation through FcoRI has therefore been proposed to function as a self-contained positive feedback loop of immune cell recruitment to clear invading pathogens and maintain homeostasis (Figure 2E). ${ }^{33}$ Alveolar macrophages, which express an alternatively spliced variant of FcaRI, also contribute to host-pathogen defense by clearance of inhaled antigens that were opsonized by IgA. ${ }^{164}$ A recent study showed that antibodies from patients with latent TB induced enhanced macrophage killing of intracellular Mtb. ${ }^{165}$ Since IgA levels against TB antigens distinguished patients with pulmonary $\mathrm{TB}$, patients with latent $\mathrm{TB}$, and non-infected individuals, a role for FcaRI-mediated effector functions in Mtb control is predicted, although this is formally not yet established. ${ }^{166}$ Interestingly, a recent study showed that Fc $\alpha$ RI also acts as an innate receptor, by binding bacteria directly independent of its ligands IgA or CRP. Binding of bacteria to Fc $\alpha$ RI induced phagocytosis by $\mathrm{CD}_{11 \mathrm{c}^{+}} \mathrm{DCs}$ and monocytes/ macrophages. Moreover, Fc $\alpha$ RI transgenic mice were protected against two different sepsis-induced models, identifying Fc $\alpha$ RI as a first-line innate receptor for bacterial clearance. $^{167}$

The contribution of antibody-dependent cellular phagocytosis (ADCP) in protective immune responses against viruses remains debatable. Nonetheless, there is substantial evidence that supports the involvement of ADCP in protection against several types of viruses and reduction of disease. ${ }^{168}$ It has been described that human NK cells and neutrophils perform ADCC and ADCP of HIV-1 gp120pulsed target CEM-NKr cells or gp120-coated beads, respectively, in the presence of polyclonal antibodies from different HIV-positive subject groups. ${ }^{169}$ Moreover, HIV-1 gp41 envelope-specific IgA induced FcaRImediated ADCC of HIV-1 Clade A- and B-infected target cells by monocytes. ${ }^{170} \mathrm{HIV}-1$ gp41 envelope-specific IgA additionally triggered ADCP of HIV-1 infected $\mathrm{CD}^{+}$ $\mathrm{T}$ cells by monocytes and neutrophils more efficiently than anti-gp41 IgGs. ${ }^{171}$ Fc $\alpha$ RI-mediated neutrophil phagocytosis initiated by vaccine-induced $\operatorname{IgA}$ was associated with reduced risk of infection against simian immunodeficiency virus (SIV) after immunization via the nasal, but not the intramuscular route in non-human primates. ${ }^{172}$ These studies may provide new insights into FcaRImediated immune responses against HIV-1 infected cells and address the potential functions of IgA during viral infections. By contrast, the RV144 HIV-1 vaccine trial showed that $\operatorname{IgA}$ interfered with IgG-mediated ADCC by NK cells of HIV-1 infected cells. ${ }^{173}$ It was proposed that Env-specific IgA competed with IgG for NK cell-mediated ADCC of HIV-1 infected cells, while enhancing ADCP by FcaRI-expressing cells like neutrophils, which represent the dominant phagocyte population in tissues from the lower female reproductive tract.

The severity of infections increases when invading pathogens from the respiratory- or gastrointestinal tract enter the bloodstream. In mice it was shown that serum IgA directed against commensal bacteria protected mice against lethal sepsis when the intestinal barrier was damaged, suggesting that serum IgA provided protection against systemic infection. ${ }^{103}$ Mice lacking pIgR and SIgA have epithelial barrier disruption, enhanced numbers of IgA-secreting plasma cells, and increased levels of serum $\operatorname{IgG}$ and $\operatorname{IgA} .^{174}$ It was furthermore demonstrated that in human FcoRI-transgenic mice IgA-opsonized bacteria in the circulation were phagocytosed by Kupffer cells, which express Fc $\alpha \mathrm{RI}^{27}$ Fc $\alpha \mathrm{RI}$ cross-linking by serum IgA immune complexes and cross-talk with pathogen recognition receptors (PRRs) on Kupffer cells initiated the release of pro-inflammatory cytokines such as TNF- $\alpha$, IL- $1 \beta$, and IL-6. ${ }^{175,176}$ As such, clearance of serum IgA-coated bacteria by Kupffer cells may act as a systemic line of defense, through elimination of invasive bacteria that have escaped mucosal immune responses (Figure 3 ).

\section{Bacterial Evasion Mechanisms}

Pathogens have evolved and developed strategies to either disarm IgA or evade FcaRI-mediated activation of immune cells, emphasizing the importance of IgA-FcaRI interactions in the elimination of pathogens and prevention of infection. ${ }^{177}$ Pathogens that colonize the oral and upper respiratory mucosa like $S$. pneumoniae and $N$. meningitides produce specific proteases cleaving both mucosal and serum IgA1 at the hinge region, which abrogates its protective effects and interferes with host antibacterial immunity. ${ }^{178,179}$ Binding of pneumococcal surface protein ( $\mathrm{Sps} \mathrm{A}$ ) to $\mathrm{SIgA}$ is suggested to recruit SIgA to the bacterial surface to promote its degradation by IgA proteases, hinder SIgA from clearing bacteria, or block the interaction between SIgA and Fc $\alpha$ RI thereby preventing immune responses. ${ }^{53}$ Additionally, IgA1 proteases were shown to degrade lysosomal-associated membrane protein 1 (LAMP-1) promoting intracellular bacterial survival in epithelial cells in vitro. ${ }^{180}$ Furthermore, it was described that serine proteases do not only cleave IgA1, which prevents FcaRImediated immune responses but also reduce the binding 


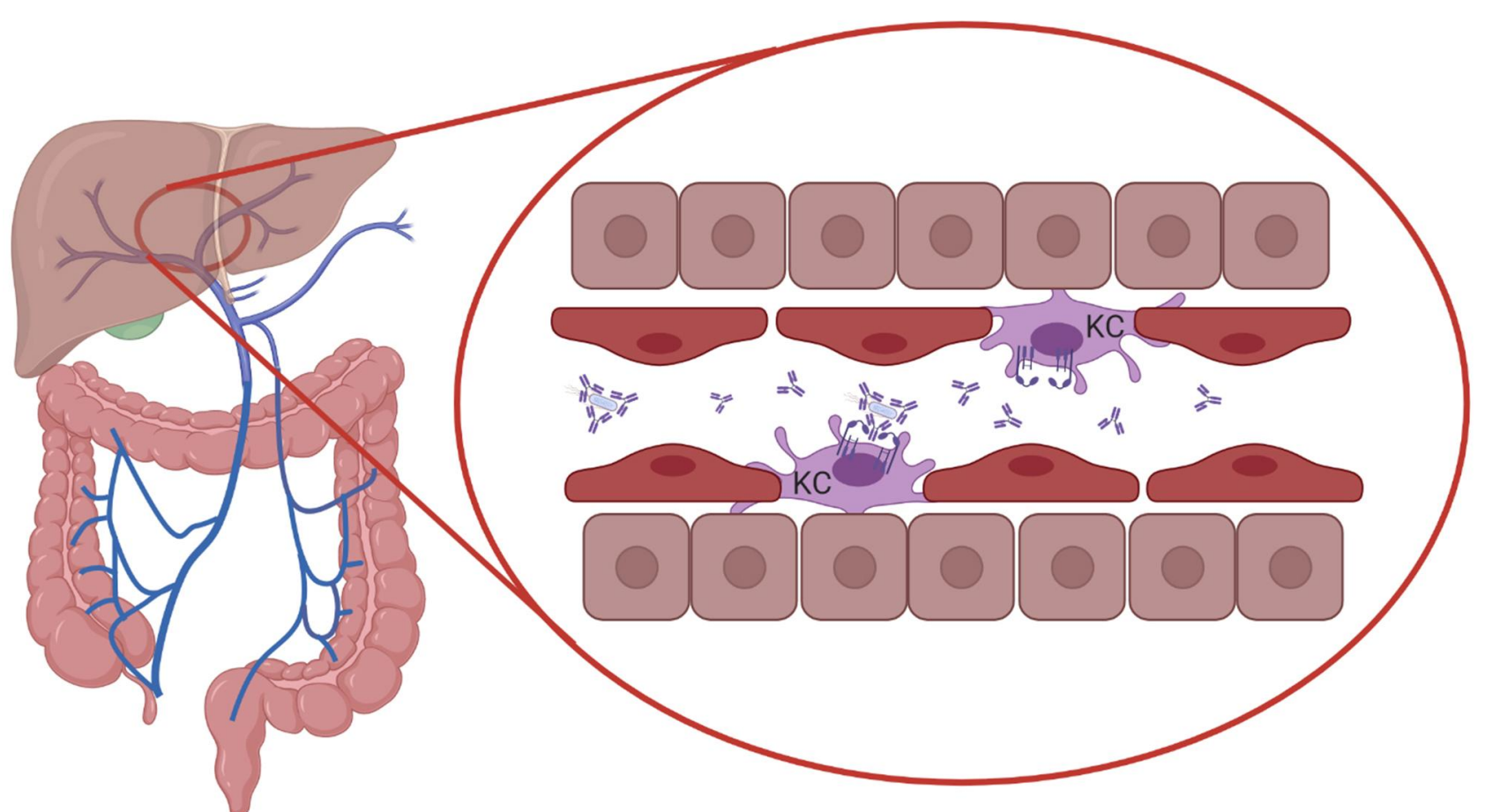

Figure 3 Systemic protection by serum IgA and FcaRI-expressing Kupffer cells. Serum IgA-opsonized bacteria in the circulation are transported to the liver through the portal vein and phagocytosed by Kupffer cells $(\mathrm{KC})$, which express FcaRI, providing protection against systemic infection. Cross-talk between FcaRI and pathogen recognition receptors (PRRs) may break the tolerance of Kupffer cells to bacterial structures. Created with BioRender.com.

avidity of IgA1 thereby reducing the neutralizing ability of IgA1 ${ }^{181}$ Closely related strains of $N$. meningitides, as well as $S$. pneumoniae that lack IgA1 proteases are considered nonvirulent. ${ }^{182}$ Furthermore, Staphylococcus aureus (S. aureus) and group A and B streptococci developed evasion mechanisms to circumvent FcaRI-mediated elimination by secreting decoy proteins that inhibit binding of $\operatorname{IgA}$ to Fc $\alpha$ RI. Decoy proteins Sir22, Arp4, and an unrelated $\beta$ protein from group B streptococci, as well as staphylococcal superantigen-like protein seven that is produced by $S$. aureus, bind to specific $\mathrm{Fc}$ residues in the $\mathrm{C} \alpha 2$ and $\mathrm{C} \alpha 3$ domains of IgA. ${ }^{183,184}$ The ability of bacteria to escape FcaRI-mediated immunity enhances survival in mucosal environments and may contribute to systemic infections.

\section{FcaRI and IgA: Chronic Inflammation and Autoimmunity}

Because FcaRI potently activates immune cells, aberrant IgA responses may contribute to pathogenesis in inflammatory and/or autoimmune diseases. The presence of $\operatorname{IgA}$ autoantibodies, aberrant IgA glycosylation, or excessive IgA immune complexes can contribute to chronic inflammation and tissue damage. The detrimental role of IgA and FcaRI-mediated immune responses has been proposed in several inflammatory diseases like IgA nephropathy, rheumatoid arthritis, IgA vasculitis, dermatitis herpetiformis, linear IgA bullous disease, and inflammatory bowel disease.

\section{IgA Nephropathy}

IgA nephropathy (IgAN) is the most common IgAmediated autoimmune disease. It is characterized by primary glomerulonephritis, resulting in chronic renal failure in $30 \%$ of the patients. ${ }^{185,186}$ Infections or microbiome dysbiosis prior to IgAN have been suggested to initiate abnormal IgA1 glycosylation as glycosyltransferases are regulated by bacterial products. ${ }^{187}$ Elevated synthesis of galactose-deficient IgA1 (gd-IgA1) triggers the production of anti-glycan antibodies. IgA immune complexes can deposit in the glomeruli inducing mesangial proliferation and matrix expansion, which eventually initiates renal injury. ${ }^{188}$ The release of pro-inflammatory cytokines such as TNF- $\alpha$, IL- 6 , and TGF- $\beta$ by mesangial cells after IgA immune complex binding was suggested to induce inflammation and glomerulosclerosis. ${ }^{187,189}$ In mice, gd-IgA1 immune complexes were not cleared from the circulation and deposited in the kidney. Shedding of Fc $\alpha$ RI in transgenic mice however resulted in the deposition of soluble 
FcaRI-IgA immune complexes in the mesangium, which induced glomerular and interstitial macrophage infiltration, hematuria, mesangial matrix expansion, and mild proteinuria. ${ }^{190-192}$ Soluble Fc $\alpha$ RI-IgA complexes additionally mediated kidney inflammation by interacting with TfR1 on mesangial cells, resulting in the release of proinflammatory mediators. ${ }^{190}$ Human Fc $\alpha$ RI transgenic mice developed IgAN after injection of serum $\operatorname{IgA}$ of $\operatorname{IgAN}$ patients. Furthermore, human IgA1 knock-in mice that had been crossed with FcoRI transgenic mice already developed IgAN in 6 weeks. ${ }^{193}$ These data clearly support the contribution of IgA and FcaRI-mediated inflammation in IgAN.

\section{Rheumatoid Arthritis}

Rheumatoid arthritis (RA) is a systemic and chronic autoimmune disorder characterized by inflammation in the joints, which frequently leads to joint destruction and disability. ${ }^{194}$ Although the etiology of RA is unknown, the presence of autoantibodies is a distinctive feature of RA. In particular, IgM rheumatoid factor (RF) and IgG anti-citrullinated protein antibodies (ACPA) are commonly used for diagnosing and classifying RA. ${ }^{195}$ Interestingly, elevated levels of IgA RF, but not of IgM- or IgG RF, correlated with worse disease prognosis and extra-articular manifestations in RA. ${ }^{196}$ Additionally, high levels of IgA RF were associated with a poor response rate to TNF- $\alpha$ blockers as therapeutic agents in advanced RA. ${ }^{197}$ In IgM RF negative patients it was shown that IgA ACPA was associated with disease severity based on disease activity score. ${ }^{15}$ RF or ACPA can be elevated in the serum years prior to the onset of clinical disease, referred to as preclinical RA. ${ }^{198,199}$ An increased number of $\operatorname{IgA}^{+}$plasmablasts was identified in preclinical RA without a history of or current inflammatory arthritis. ${ }^{200}$ In both clinical and preclinical RA, IgA ACPA was highly specific for RA. ${ }^{201,202}$ IgA ACPA and RF immune complexes furthermore increased the release of pro-inflammatory cytokines such as TNF- $\alpha$, IL- $1 \beta$, and IL- 6 by myeloid cells via crosslinking of FcaRI, whereas blocking of FcaRI on macrophages resulted in reduced levels of TNF- $\alpha .{ }^{203}$ Additionally, increased NET release by neutrophils in the presence of plasma of RA patients containing IgA RF was demonstrated, which was dependent on FcoRI. ${ }^{78}$ Altogether, this supports that IgA contributes to disease, as activation of FcaRI-expressing neutrophils and macrophages in the joint via IgA auto-immune complexes likely enhances inflammation and pathology of RA.

\section{IgA Vasculitis}

IgA vasculitis, formerly known as Henoch-Schönlein purpura, is the most common form of vasculitis involving the small vessels of the joints, kidneys, gastrointestinal tract, and the skin. ${ }^{204}$ Although the etiology of IgA vasculitis remains unknown, the disease is characterized by $\operatorname{IgA} 1$ immune deposits and neutrophil infiltrates damaging the small vessels. Abnormal glycosylation of the hinge region of $\operatorname{IgA} 1$ is suggested to cause aggregation into macromolecular immune complexes. ${ }^{204}$ Fc $\alpha$ RI-mediated cross-linking of neutrophils induces inflammatory processes like ROS production, NET formation, and LTB4 release. As such, it is hypothesized that Fc $\alpha$ RI-mediated activation of neutrophils results in vessel damage and leakage of red blood cells into the skin causing typical cutaneous hemorrhages. ${ }^{14}$ Antigen recognition sites of accumulated $\operatorname{IgA} 1$ in $\operatorname{IgA}$ vasculitis have not yet been identified. However, it was proposed that these antibodies can recognize epitopes on endothelial cells as serum IgA from IgA vasculitis patients was shown to bind to human but not bovine glomerular endothelial cells in vitro. ${ }^{205}$ Notably, sera of IgA vasculitis patients had increased levels of soluble FcaRI-IgA complexes, which was associated with decreased Fc $\alpha$ RI expression on monocytes. ${ }^{206}$ A positive feedback loop of inflammation in IgA vasculitis was proposed, since binding of $\operatorname{IgA} 1$ antibodies to endothelial cells induced the release of IL- 8 , thereby attracting more neutrophils that can be activated through FcoRI. ${ }^{16}$

\section{Skin Blistering Diseases}

Dermatitis herpetiformis (DH) is an autoimmune disease that often occurs in combination with gluten-sensitive enteropathy (celiac disease). Anti-transglutaminase $\operatorname{IgA}$ antibodies (mainly anti-epidermal transglutaminase 3; TGase3) play a key role in disease pathogenesis of $\mathrm{DH}$ as it was shown that serum anti-epidermal transglutaminase IgA positively correlated with disease activity. ${ }^{207} \mathrm{IgA}$ anti-tissue transglutaminase antibodies form immune complexes and deposit in the dermis of patients with $\mathrm{DH} .{ }^{12}$ In the skin, transglutaminase/IgA immune complexes induce fibrinolysis, which directly contributes to blister formation in $\mathrm{DH}$, and results in chemotaxis of neutrophils and monocytes. ${ }^{208,209}$ Accumulating FcoRI-positive neutrophils in the skin of DH had increased ability to bind IgA. As such, they presumably bind transglutaminase/IgA immune complexes and induce cellular activation contributing to tissue damage. ${ }^{210,211}$ Released proteolytic enzymes by activated neutrophils can induce sub-epidermal split by cleaving adhesion molecules 
such as collagen VII. ${ }^{212}$ Circulating epidermal transglutaminase/IgA immune complexes have been detected in patients with DH which, together with disease manifestations, decrease over time after following a gluten-free diet. ${ }^{213}$ Some DH patients also showed IgA immune complex deposition in the kidney, which ultimately can lead to $\operatorname{IgA}$ nephropathy $(\operatorname{IgAN}){ }^{213}$

Similar to DH, linear IgA bullous disease (LABD) is a skin blistering disease characterized by IgA autoantibodies against collagen XVII and FcaRI-mediated neutrophil activation. ${ }^{214}$ It was shown in an ex vivo skin model that activated neutrophils in the presence of serum of LABD patients (containing anti-collagen XVII IgA) caused the separation of dermis from epidermis (Figure 4). This separation, reflecting blister formation in LABD patients, was prevented by blocking IgA-Fc $\alpha$ RI interaction on neutrophils. ${ }^{215}$ Additionally, eosinophil influx has also been observed in the skin of LABD, which may contribute to LABD pathology through FcaRI-mediated respiratory burst activity. ${ }^{214,215}$

\section{Inflammatory Bowel Disease}

Inflammatory bowel disease (IBD) is characterized by chronic inflammation of the gastrointestinal tract and disruption of the epithelium. IBD can be subdivided into two major forms, ulcerative colitis (UC) and Crohn's disease (CD). ${ }^{216}$ The etiology of IBD is ill-understood, but likely

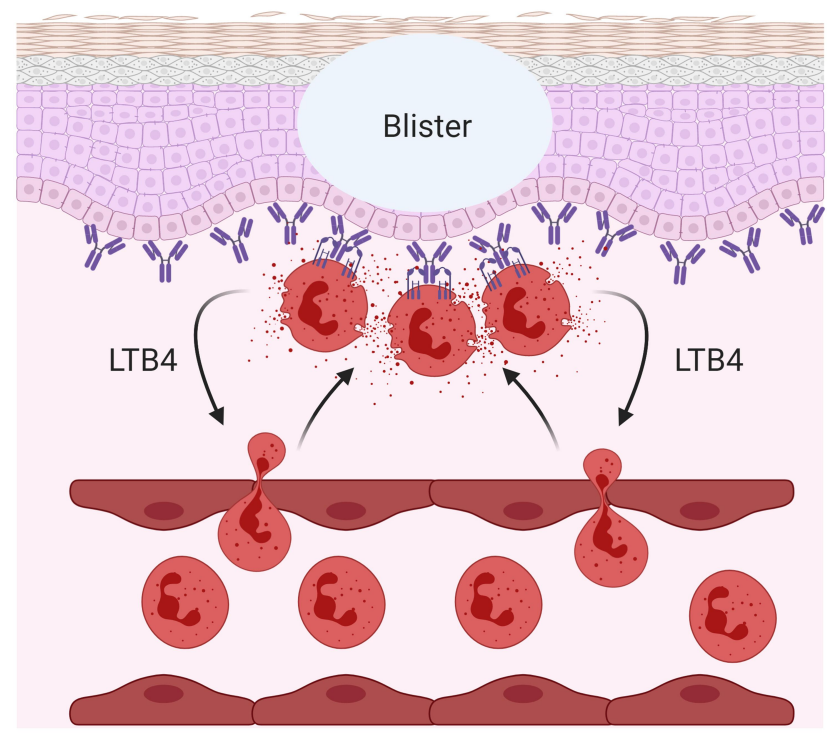

Figure $4 \mathrm{lgA}-\mathrm{Fc} \alpha \mathrm{RI}$ induced pathology in skin blistering diseases. Cross-linking of $\mathrm{Fc} \alpha \mathrm{RI}$ on neutrophils with IgA immune complexes results in the release of leukotriene B4 (LTB4) inducing enhanced neutrophil influx, causing tissue damage in a variety of inflammatory- and autoimmune diseases. An example is the blister formation in linear IgA bullous disease (LABD). Created with BioRender.com. involves derailed immune responses against commensal bacteria. Fecal bacteria of patients with IBD, that were highly opsonized with IgA,induced colitis in germ-free mice. ${ }^{217}$ Furthermore, fecal bacteria in IBD patients showed increased opsonization with $\operatorname{IgA}$ compared to healthy individuals, suggesting that leakage of serum IgA or dIgA through the disrupted epithelial layer contributes to enhanced opsonization. ${ }^{217,218}$ In line with this, it was shown that IBD patients have increased levels of specific IgA against microbiota in their serum. ${ }^{219}$ The percentage of IgA-opsonized bacteria in CD strongly correlated with multiple clinical indexes of disease activity and may therefore be useful for monitoring $\mathrm{CD} .{ }^{220}$ Due to the disruption of the intestinal epithelial barrier in these patients, bacteria are able to invade the sub-epithelial lamina propria and are likely opsonized with dIgA. This may subsequently induce neutrophil activation via FcaRI cross-linking, since uptake of IgA complexes by neutrophils was observed in the mucosa of patients with UC. ${ }^{79}$ Fc $\alpha$ RI-mediated neutrophil activation induces migration through the release of LTB4. It was therefore hypothesized that in UC patients a continuous neutrophil recruitment loop is initiated. Newly recruited neutrophils will be activated by IgAopsonized bacteria and initiate a feedback loop of neutrophil chemotaxis, which eventually results in tissue damage. ${ }^{79}$ Moreover, cross-talk of FcaRI and toll-like receptor 4 (TLR4) on neutrophils resulted in enhanced release of pro-inflammatory TNF- $\alpha$, which plays a central role in IBD pathogenesis. ${ }^{221,222}$ Excessive influx of neutrophils causing major tissue damage was demonstrated in UC patients. ${ }^{222}$ As such, a role for IgA and FcaRI is proposed in especially $\mathrm{UC}$, but their exact roles still need to be established.

\section{FcaRI and IgA: Therapeutic Opportunities IgA Vaccination Strategies}

Inducing pathogen-specific mucosal and systemic IgA through passive or active immunization may be an attractive strategy to combat bacterial and viral infections. ${ }^{223}$ Licensed oral and nasal vaccines have demonstrated to induce mucosal SIgA responses as well as system responses contributing to protection. ${ }^{223,224}$ Furthermore, mucosal application of the TB protein subunit vaccine H56/CAF01 followed by intramuscular priming induced high levels of antigen-specific lung mucosal and systemic IgA. ${ }^{225} \mathrm{Mtb}$ specific IgA may contribute to prevention of $\mathrm{TB}$, since 
mucosally administered human IgA antibodies against $M t b$ in mice provided passive protection. ${ }^{226}$ Additionally, vaccine-induced pulmonary SIgA in mice was associated with passive protection against TB. ${ }^{134,227}$ Recombinant monoclonal antibodies (mAb), generated from single isolated $B$ cells of untreated adult patients with acute pulmonary TB and from MTB-exposed healthcare workers, revealed that IgA against $M t b$ inhibited mycobacterial infection of human epithelial-like and macrophage-like cells, whereas IgG promoted infection. ${ }^{126}$ Thus, it is suggested that IgA may be particularly important for protection against TB infection. $^{228}$ This is supported by experiments with human Fc $\alpha$ RI transgenic mice, which had a lower $M t b$ infection rate compared to control WT mice after inoculation of human IgA mAbs, implicating an important role for Fc $\alpha$ RI in clearing $M t b$ infection. $^{226}$ Nasal immunization with pneumococcal surface protein A (PspA) and cholera toxin as adjuvant elicited PspA-specific mucosal IgA and systemic IgG antibody responses, which provided protection against colonization of $S$. pneumoniae and pneumococcal infection in mice. ${ }^{229}$ PspA-specific SIgA effectively neutralized colonized $S$. pneumoniae, diminished nasal carriage and prevented subsequent infection with S. pneumoniae. IgA-deficient mice failed to prevent nasal colonization by $S$. pneumoniae, in spite of having functional anti-PspA IgG antibodies in the nasal cavity, stating the necessity of specific IgA to prevent infection. ${ }^{230}$

Vaccine-induced IgA also provides effective protection against viral infections. Both the inactivated and the liveattenuated oral poliovirus vaccines, which played a tremendous role in the elimination of the poliovirus, induced potent-specific IgA responses. ${ }^{231}$ Oral vaccines consisting of live attenuated rotavirus (RV) mediate significantly reduced disease. Serum rotavirus-specific IgA (RV-IgA) correlated with vaccine efficacy and protective immunity. ${ }^{232}$ IgA knockout, as well as J-chain knockout mice, showed delayed viral clearance and absence of protective immunity, supporting the critical role of IgA in RV immunity. ${ }^{233,234}$ Interestingly, in both humans and animals, RV-IgA can persist for a long time, suggesting the presence of long-lived $\mathrm{IgA}^{+}$plasma cells. ${ }^{235}$ Similar to $\mathrm{RV}$, it has been shown that vaccination with live attenuated poliovirus induced long-lived IgA memory immune responses in elderly. ${ }^{236}$ Intravenous administration of polymeric IgA against influenza showed protection against infection in mice. Inhibition of influenza virus shedding by IgA was 10 times more effective than $\operatorname{IgG}^{237}$ Additionally, IgA antibodies against influenza A virus hemagglutinin, purified from respiratory tract washings of hemagglutinin immunized mice, were able to protect naïve mice from influenza infection. ${ }^{238}$ Similar protective effects of $\operatorname{IgA}$ were shown in mice that received passive oral administration of $\operatorname{IgA}$ against reovirus-specific adhesion molecule sigmal, which prevented entry of reovirus into the Peyer's patches. Since IgG mAbs against sigmal did not prevent Peyer's patch infection by reovirus, this effect was IgA specific. ${ }^{239}$ Thus, inducing systemic and mucosal IgA responses through vaccination may play an important role in either passive or active protection against pathogens (Figure 5). Notably, the adjuvant alum, which is currently used in many injectable vaccines does not effectively induce IgA class-switching. ${ }^{240}$ Newly developed mucosal adjuvants like TLR agonists and toxin derivatives (ADPribosyltransferase enterotoxins and adenylate cyclase toxins) are suggested to improve IgA responses in vaccination strategies. $^{241}$ Thus, inducing enhanced $\operatorname{IgA}$ responses through vaccination represents a promising therapeutic strategy for future vaccine development.

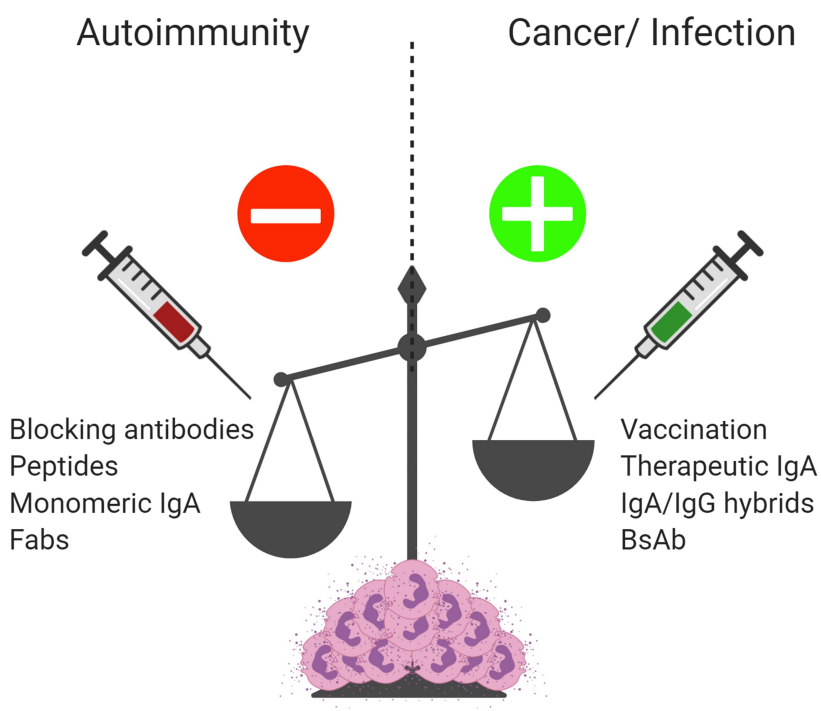

Figure $5 \lg \mathrm{A}$ and $\mathrm{F} c \alpha \mathrm{RI}$ as therapeutic targets. Enhanced $\lg \mathrm{A}$ complexes or autoantibodies result in excessive activation of immune cells contributing to chronic inflammation and tissue damage in autoimmune diseases. Blocking IgA-FcaRI interactions by either monoclonal antibodies or peptides may reduce inflammation and tissue damage in these diseases. Treatment with monomeric IgA or anti-FcaRI Fabs may dampen immune responses by inducing inhibitory ITAM signaling and inhibiting IgG-induced phagocytosis and IgE-mediated allergic diseases. To combat bacterial and viral infections, inducing pathogen-specific IgA via passive or active vaccination may result in enhanced protective immunity. Enhancing pro-inflammatory responses by $\mathrm{FcaRI-expressing} \mathrm{immune} \mathrm{cells} \mathrm{via} \mathrm{IgA} \mathrm{monoclonal} \mathrm{antibody} \mathrm{therapy,} \mathrm{bi-specific}$ antibodies, or cross-isotype hybrid antibodies may result in efficient killing of tumor cells and represent a promising therapeutic opportunity for cancer patients. Created with BioRender.com. 


\section{Promoting FcaRI-Mediated Anti-Tumor Immunity}

IgA or FcaRI bispecific antibodies have been proposed as novel drugs to treat cancer by enhancing activation of FcaRIexpressing immune cells. ${ }^{242-245}$ Tumor cell killing by neutrophils was superior after targeting Fc $\alpha$ RI, compared with targeting to IgG Fc receptors, which was demonstrated for several tumor antigens such as EGFR, HER2, EpCAM, HLA-II, CD20, CD30, and carcinoembryonic antigen. $^{242,245,246}$ Treatment of Fc $\alpha$ RI transgenic mice with anti-tumor IgA mAbs against CD20, HER2, or EGFR resulted in enhanced migration of Fc $\alpha \mathrm{RI}$-expressing immune cells and significantly increased anti-tumor cytotoxicity, which was mostly mediated by FcaRI-expressing macrophages. $^{243,247,248}$ However, in contrast to IgG, IgA mAbs cannot activate natural killer cells, which do not express Fc $\alpha$ RI. Moreover, IgA is a poor complement activator and has a shorter half-life compared to IgG. IgA therapeutic antibodies that are produced in non-human systems contain different glycosylation profiles, which may also enhance immunogenicity and are likely to be cleared from the human circulation. ${ }^{12}$ Alternatively, the efficacy of Fc $\alpha$ RI bispecific antibodies targeting both tumor antigens and FcaRI has been investigated. FcaRI bispecific antibodies efficiently induced neutrophil migration in vitro, which was not observed after targeting Fc $\gamma$ receptors. ${ }^{249}$ Additionally, tumor cell killing was more effective. ${ }^{250,251}$ Engineering of a cross-isotype antibody that contains merged Fc domain residues from IgG1 and $\operatorname{IgA}$, combining the effector functions of both isotypes, mediated increased complementdependent cytotoxicity and $\mathrm{Her}^{+}$tumor cell killing by both neutrophils and macrophages. ${ }^{252}$ Furthermore, it was shown that anti-epidermal growth factor receptor-2 $\operatorname{IgG} 1 / \operatorname{IgA} 2$ cross-isotype antibodies induced increased recruitment of neutrophils, resulting in enhanced ADCC of human breast cancer cells by neutrophils. ${ }^{253}$ Pharmacokinetics of IgG and IgA cross-isotype antibodies were similar to the parental IgG antibodies and may therefore augment IgG-based antibody therapies. $^{253}$ Thus, antibody-based strategies that target Fc $\alpha$ RI represent a promising therapeutic opportunity for cancer patients (Figure 5).

\section{Inhibiting FcaRI-Mediated Immunity}

Naturally occurring serum $\operatorname{IgA}$ was shown to dampen immune responses by inducing ITAMi signaling via Fc $\alpha$ RI (Figure 1A). ${ }^{8}$ Enhancing ITAMi signaling by monovalent targeting of Fc $\alpha$ RI has been proposed as a promising strategy to inhibit IgG-induced phagocytosis and IgE-mediated allergic diseases (Figure 5). ${ }^{254}$ Monovalent targeting of FcaRI with the anti-FcoRI mAb A77 inhibited degranulation of RBL-2H3 transfected cells. ${ }^{8}$ In in vivo models for allergic asthma and arthritis, FcoRI transgenic mice had reduced airway inflammation or resolution of arthritis after monovalent targeting of FcoRI. ${ }^{254,255}$ Additionally, targeting of FcoRI by mAb A77 suppressed inflammation in transgenic mice with IgG immune complex-induced glomerulonephritis and obstructive nephropathy. ${ }^{256}$ Renal inflammation induced by $\mathrm{CpG}$ dinucleotides (TLR9 agonist) in FcaRI transgenic mice was downregulated by monomeric targeting of FcaRI as well. $^{257}$ Thus, monomeric targeting of Fc $\alpha$ RI was shown to induce anti-inflammatory properties, which could be used as treatment of inflammatory diseases with involvement of myeloid cells (Figure 5). Alternatively, blocking Fc $\alpha$ RI with $\mathrm{mAb}$ MIP8a inhibited cytokine production, leukocyte recruitment, and inflammation in a lupus nephritis model. ${ }^{258}$ Fc $\alpha$ RI blocking also reduced NET release by neutrophils that had been stimulated with IgA immune complexes obtained from serum and synovial fluid of RA patients. $^{259}$ Similarly, in an ex vivo LABD skin model, Fc $\alpha$ RI blocking with MIP8a prevented IgA-induced neutrophil-mediated blister formation. ${ }^{215}$ In a recent study, peptides targeting the interaction sites of IgA and FcoRI were suggested as novel therapeutic strategy for IgA-mediated skin autoimmune diseases, as these peptides were able to penetrate into human skin ex vivo and reduced IgA-induced neutrophil migration. ${ }^{260}$ As such, blocking FcoRI-IgA interactions represents a promising therapeutic strategy for IgAassociated inflammatory diseases and autoimmunity (Figure 5).

\section{Concluding Remarks and Future Perspectives}

IgA and FcaRI-mediated cell activation is important for maintaining homeostasis and preventing infections. SIgA contributes to passive immunity at mucosal surfaces by neutralizing pathogens, whereas active immunity is provided by dIgA and serum IgA through induction of Fc $\alpha$ RI-mediated activation of myeloid cells. Future research regarding vaccination and infectious diseases should therefore also include serological and functional studies of IgA and FcaRImediated immune responses. It is becoming clear that the presence of overabundant IgA complexes or autoantibodies can result in excessive activation and recruitment of immune cells contributing to tissue damage and the development of 
chronic inflammation in multiple diseases. A better understanding of the IgA-FcoRI axis in health and disease can provide multiple options for therapeutic interventions. On the one hand, immune responses against pathogens or cancer cells may be enhanced by vaccination or passive transfer of therapeutic IgA. On the other hand, initiating inhibitory ITAM signaling by monomeric targeting of Fc $\alpha$ RI or blocking IgA-FcaRI interactions with mAbs or peptides can dampen inflammation and disease.

\section{Highlights}

- SIgA contributes to mucosal homeostasis and passive immunity through immune exclusion and by diversifying the gut microbiome

- Monomeric IgA induces inhibitory signaling, whereas active immunity is provided by complexed $\operatorname{dIgA}$ and serum IgA through cross-linking of FcaRI on myeloid cells

- Pathogen-specific IgA is associated with protection against infections

- Altered IgA glycosylation or excessive IgA immune complexes contribute to chronic inflammation and autoimmunity through FcoRI-mediated immune activation

- Understanding the IgA-Fc $\alpha$ RI axis during infection and autoimmunity will provide new therapeutic opportunities.

\section{Disclosure}

The authors report no conflicts of interest for this work.

\section{References}

1. Belkaid Y, Harrison OJ. Homeostatic immunity and the microbiota. Immunity. 2017;46(4):562-576. doi:10.1016/j.immuni.2017.04.008

2. Lu LL, Suscovich TJ, Fortune SM, Alter G. Beyond binding: antibody effector functions in infectious diseases. Nat Rev Immunol. 2018;18 (1):46-61. doi:10.1038/nri.2017.106

3. Dimitrov JD, Lacroix-Desmazes S. Noncanonical functions of antibodies. Trends Immunol. 2020;41(5):379-393. doi:10.1016/j. it.2020.03.006

4. Bruhns P, Jonsson F. Mouse and human FcR effector functions. Immunol Rev. 2015;268(1):25-51. doi:10.1111/imr.12350

5. Macpherson AJ, Yilmaz B, Limenitakis JP, Ganal-Vonarburg SC. IgA function in relation to the intestinal microbiota. Annu Rev Immunol. 2018;36(1):359-381. doi:10.1146/annurev-immunol-042617-053238

6. Pabst O, Slack E. IgA and the intestinal microbiota: the importance of being specific. Mucosal Immunol. 2020;13(1):12-21. doi:10.1038/ s41385-019-0227-4

7. Leong KW, Ding JL. The unexplored roles of human serum IgA. DNA Cell Biol. 2014;33(12):823-829. doi:10.1089/dna.2014.2639

8. Pasquier B, Launay P, Kanamaru Y, et al. Identification of FcalphaRI as an inhibitory receptor that controls inflammation: dual role of FcRgamma ITAM. Immunity. 2005;22(1):31-42. doi:10.1016/j. immuni.2004.11.017
9. Mkaddem SB, Christou I, Rossato E, Berthelot L, Lehuen A, Monteiro RC. $\operatorname{IgA}, \operatorname{IgA}$ receptors, and their anti-inflammatory properties. Curr Top Microbiol Immunol. 2014;382:221-235. doi:10.1007/978-3-319-07911-0_10

10. Aleyd E, Heineke MH, van Egmond M. The era of the immunoglobulin A Fc receptor FcalphaRI; its function and potential as target in disease. Immunol Rev. 2015;268(1):123-138. doi:10.1111/imr.12337

11. Davis SK, Selva KJ, Kent SJ, Chung AW. Serum IgA Fc effector functions in infectious disease and cancer. Immunol Cell Biol. 2020;98(4):276-286. doi:10.1111/imcb.12306

12. Breedveld A, van Egmond M. IgA and FcalphaRI: pathological roles and therapeutic opportunities. Front Immunol. 2019;10:553. doi:10.3389/fimmu.2019.00553

13. Sallustio F, Curci C, Di Leo V, Gallone A, Pesce F, Gesualdo L. A new vision of IgA nephropathy: the missing link. Int J Mol Sci. 2019;21(1):189. doi:10.3390/ijms21010189

14. Heineke $\mathrm{MH}$, Ballering $\mathrm{AV}$, Jamin $\mathrm{A}$, Ben Mkaddem $\mathrm{S}$, Monteiro RC, Van Egmond M. New insights in the pathogenesis of immunoglobulin A vasculitis (Henoch-Schonlein purpura). Autoimmun Rev. 2017;16(12):1246-1253. doi:10.1016/j. autrev.2017.10.009

15. Karimifar M, Moussavi H, Babaei M, Akbari M. The association of immunoglobulin A, immunoglobulin G and anti-cyclic citrullinated peptide antibodies with disease activity in seronegative rheumatoid arthritis patients. J Res Med Sci. 2014;19(9):823-826.

16. Yang YH, Huang YH, Lin YL, et al. Circulating IgA from acute stage of childhood Henoch-Schonlein purpura can enhance endothelial interleukin (IL)-8 production through MEK/ERK signalling pathway. Clin Exp Immunol. 2006;144(2):247-253. doi:10.1111/j.1365-2249.2006.03076.x

17. Di Niro R, Mesin L, Zheng NY, et al. High abundance of plasma cells secreting transglutaminase 2 -specific IgA autoantibodies with limited somatic hypermutation in celiac disease intestinal lesions. Nat Med. 2012;18(3):441-445. doi:10.1038/nm.2656

18. Mercieca C, van der Horst-bruinsma IE, Borg AA. Pulmonary, renal and neurological comorbidities in patients with ankylosing spondylitis; implications for clinical practice. Curr Rheumatol Rep. 2014;16(8):434. doi:10.1007/s11926-014-0434-7

19. Torruellas C, French SW, Medici V. Diagnosis of alcoholic liver disease. World J Gastroenterol. 2014;20(33):11684-11699. doi:10.3748/wjg.v20.i33.11684

20. Lopez E, Shattock RJ, Kent SJ, Chung AW. The multifaceted nature of immunoglobulin A and its complex role in HIV. AIDS Res Hum Retroviruses. 2018;34(9):727-738. doi:10.1089/ aid.2018.0099

21. Kremer EJ, Kalatzis V, Baker E, Callen DF, Sutherland GR, Maliszewski CR. The gene for the human IgA Fc receptor maps to 19q13.4. Hum Genet. 1992;89(1):107-108.

22. Nimmerjahn F, Ravetch JV. Fcgamma receptors: old friends and new family members. Immunity. 2006;24(1):19-28. doi:10.1016/j. immuni.2005.11.010

23. Monteiro RC, Van De Winkel JG. IGAFC receptors. Annu Rev Immunol. 2003;21(1):177-204. doi:10.1146/annurev. immunol.21.120601.141011

24. de Wit TP, Morton HC, Capel PJ, van de Winkel JG. Structure of the gene for the human myeloid IgA Fc receptor (CD89). J Immunol. 1995;155(3):1203-1209.

25. Herr AB, Ballister ER, Bjorkman PJ. Insights into IgA-mediated immune responses from the crystal structures of human FcalphaRI and its complex with IgA1-Fc. Nature. 2003;423 (6940):614-620. doi:10.1038/nature01685

26. Pfefferkorn LC, Yeaman GR. Association of IgA-Fc receptors (Fc alpha R) with Fc epsilon RI gamma 2 subunits in U937 cells. Aggregation induces the tyrosine phosphorylation of gamma 2. J Immunol. 1994;153(7):3228-3236. 
27. van Egmond $M$, van Garderen E, van Spriel AB, et al. FcaRIpositive liver kupffer cells: reappraisal of the function of immunoglobulin A in immunity. Nat Med. 2000;6(6):680-685. doi: $10.1038 / 76261$

28. Qian K, Xie F, Gibson AW, Edberg JC, Kimberly RP, Wu J. Functional expression of IgA receptor FcalphaRI on human platelets. J Leukoc Biol. 2008;84(6):1492-1500. doi:10.1189/ jlb.0508327

29. Hansen IS, Krabbendam L, Bernink JH, et al. FcalphaRI co-stimulation converts human intestinal $\mathrm{CD} 103(+)$ dendritic cells into pro-inflammatory cells through glycolytic reprogramming. Nat Commun. 2018;9(1):863. doi:10.1038/s41467-018-03318-5

30. Heystek HC, Moulon C, Woltman AM, Garonne P, van Kooten C. Human immature dendritic cells efficiently bind and take up secretory IgA without the induction of maturation. J Immunol. 2002;168(1):102-107.

31. Monteiro RC, Cooper MD, Kubagawa H. Molecular heterogeneity of $\mathrm{Fc}$ alpha receptors detected by receptor-specific monoclonal antibodies. J Immunol. 1992;148(6):1764-1770.

32. Reljic R. In search of the elusive mouse macrophage Fc-alpha receptor. Immunol Lett. 2006;107(1):80-81. doi:10.1016/j. imlet.2006.04.014

33. Bakema JE, van Egmond M. The human immunoglobulin A Fc receptor FcalphaRI: a multifaceted regulator of mucosal immunity. Mucosal Immunol. 2011;4(6):612-624. doi:10.1038/mi.2011.36

34. Bakema JE, Hiemstra IH, Bakker J, et al. c-Jun activating binding protein 1 binds to the IgA receptor and modulates protein levels of FcalphaRI and FcRgamma-chain. Eur J Immunol. 2010;40 (7):2035-2040. doi:10.1002/eji.200939985

35. Hostoffer RW, Krukovets I, Berger M. Increased Fc alpha $\mathrm{R}$ expression and IgA-mediated function on neutrophils induced by chemoattractants. J Immunol. 1993;150(10):4532-4540.

36. Nikolova EB, Russell MW. Dual function of human IgA antibodies: inhibition of phagocytosis in circulating neutrophils and enhancement of responses in IL-8-stimulated cells. J Leukoc Biol. 1995;57(6):875-882. doi:10.1002/jlb.57.6.875

37. Yin N, Peng M, Xing Y, Zhang W. Intracellular pools of FcalphaR (CD89) in human neutrophils are localized in tertiary granules and secretory vesicles, and two FcalphaR isoforms are found in tertiary granules. $J$ Leukoc Biol. 2007;82(3):551-558. doi: $10.1189 / \mathrm{jlb} .0207112$

38. Wehrli M, Schneider C, Cortinas-Elizondo F, et al. IgA triggers cell death of neutrophils when primed by inflammatory mediators. J Immunol. 2020.

39. Maliszewski CR, Shen L, Fanger MW. The expression of receptors for IgA on human monocytes and calcitriol-treated HL-60 cells. J Immunol. 1985;135(6):3878-3881.

40. Shen L, Collins JE, Schoenborn MA, Maliszewski CR. Lipopolysaccharide and cytokine augmentation of human monocyte IgA receptor expression and function. J Immunol. 1994;152 (8):4080-4086.

41. Reterink TJ, Levarht EW, Klar-Mohamad N, Van Es LA, Daha MR. Transforming growth factor-beta 1 (TGF-beta 1) down-regulates IgA Fc-receptor (CD89) expression on human monocytes. Clin Exp Immunol. 1996;103(1):161-166.

42. Grossetete B, Launay P, Lehuen A, Jungers P, Bach JF, Monteiro RC. Down-regulation of Fc alpha receptors on blood cells of IgA nephropathy patients: evidence for a negative regulatory role of serum IgA. Kidney Int. 1998;53(5):1321-1335. doi:10.1046/j.1523-1755.1998.00885.x

43. Kawamura S, Saitou N, Ueda S. Concerted evolution of the primate immunoglobulin alpha-gene through gene conversion. J Biol Chem. 1992;267(11):7359-7367.

44. Pinheiro A, de Sousa-pereira P, Strive T, et al. Identification of a new European rabbit IgA with a serine-rich hinge region. PLoS One. 2018;13(8):e201567.
45. de Sousa-pereira P, Woof JM. IgA: structure, function, and developability. Antibodies (Basel). 2019;8(4). doi:10.3390/ antib8040057

46. Steffen U, Koeleman CA, Sokolova MV, et al. IgA subclasses have different effector functions associated with distinct glycosylation profiles. Nat Commun. 2020;11(1):120. doi:10.1038/ s41467-019-13992-8

47. Kilian M, Reinholdt J, Lomholt H, Poulsen K, Frandsen EV Biological significance of IgA1 proteases in bacterial colonization and pathogenesis: critical evaluation of experimental evidence. APMIS. 1996;104(5):321-338. doi:10.1111/j.1699-0463.1996. tb00724.x

48. Tarelli E, Smith AC, Hendry BM, Challacombe SJ, Pouria S. Human serum IgA1 is substituted with up to six O-glycans as shown by matrix assisted laser desorption ionisation time-of-flight mass spectrometry. Carbohydr Res. 2004;339(13):2329-2335. doi:10.1016/j.carres.2004.07.011

49. Royle L, Roos A, Harvey DJ, Wormald MR, van Gijlswijkjanssen D. Secretory IgA N- and O-glycans provide a link between the innate and adaptive immune systems. J Biol Chem. 2003;278(22):20140-20153. doi:10.1074/jbc.M301436200

50. Novak J, Barratt J, Julian BA, Renfrow MB. Aberrant glycosylation of the IgA1 molecule in IgA nephropathy. Semin Nephrol. 2018;38(5):461-476. doi:10.1016/j.semnephrol.2018.05.016

51. Kerr MA. The structure and function of human IgA. Biochem J. 1990;271(2):285-296. doi:10.1042/bj2710285

52. Bunker JJ, Bendelac A. IgA responses to microbiota. Immunity. 2018;49(2):211-224. doi:10.1016/j.immuni.2018.08.011

53. Wang Y, Wang G, Li Y, et al. Structural insights into secretory immunoglobulin A and its interaction with a pneumococcal adhesin. Cell Res. 2020;30(7):602-609. doi:10.1038/s41422020-0336-3

54. Johansen FE, Kaetzel CS. Regulation of the polymeric immunoglobulin receptor and IgA transport: new advances in environmental factors that stimulate pIgR expression and its role in mucosal immunity. Mucosal Immunol. 2011;4(6):598-602. doi:10.1038/mi.2011.37

55. Brandtzaeg P, Prydz H. Direct evidence for an integrated function of $\mathrm{J}$ chain and secretory component in epithelial transport of immunoglobulins. Nature. 1984;311(5981):71-73. doi:10.1038/ 311071a0

56. Kumar N, Arthur CP, Ciferri C, Matsumoto ML. Structure of the secretory immunoglobulin A core. Science. 2020;367 (6481):1008-1014. doi:10.1126/science.aaz5807

57. Herr AB. Secret(ory) revealed: the long-awaited structures of secretory IgA. Cell Res. 2020;30(7):558-559. doi:10.1038/ s41422-020-0351-4

58. Van Spriel AB, Leusen JH, Vile H. Mac-1 (CD11b/CD18) as accessory molecule for Fc alpha R (CD89) binding of IgA. J Immunol. 2002;169(7):3831-3836. doi:10.4049/jimmunol.169.7.3831

59. Reterink TJ, van Zandbergen G, van Egmond M, et al. Sizedependent effect of IgA on the IgA Fc receptor (CD89). Eur J Immunol. 1997;27(9):2219-2224. doi:10.1002/eji.1830270915

60. Pleass RJ, Dehal PK, Lewis MJ, Woof JM. Limited role of charge matching in the interaction of human immunoglobulin A with the immunoglobulin A Fc receptor (FcalphaRI) CD89. Immunology. 2003;109(3):331-335. doi:10.1046/j.13652567.2003.01677.x

61. Posgai MT, Tonddast-Navaei S, Jayasinghe M, Ibrahim GM, Stan G, Herr AB. FcalphaRI binding at the IgA1 CH2-CH3 interface induces long-range conformational changes that are transmitted to the hinge region. Proc Natl Acad Sci U SA. 2018;115(38):E8882-E91. doi:10.1073/pnas.1807478115

62. Zhang Y, Boesen CC, Radaev S, et al. Crystal structure of the extracellular domain of a human Fc gamma RIII. Immunity. 2000;13(3):387-395. doi:10.1016/S1074-7613(00)00038-8 
63. Keown MB, Henry AJ, Ghirlando R, Sutton BJ, Gould HJ. Thermodynamics of the interaction of human immunoglobulin E with its high-affinity receptor Fc epsilon RI. Biochemistry. 1998;37(25):8863-8869. doi:10.1021/bi972354h

64. Keown MB, Ghirlando R, Mackay GA, Sutton BJ, Gould HJ. Basis of the 1:1 stoichiometry of the high affinity receptor Fc epsilon RI-IgE complex. Eur Biophys J. 1997;25(5-6):471-476. doi: $10.1007 / \mathrm{s} 002490050062$

65. Sondermann P, Huber R, Oosthuizen V, Jacob U. The 3.2-A crystal structure of the human $\mathrm{IgG} 1 \mathrm{Fc}$ fragment- $\mathrm{Fc}$ gammaRIII complex. Nature. 2000;406(6793):267-273. doi: $10.1038 / 35018508$

66. Bonner A, Furtado PB, Almogren A, Kerr MA, Perkins SJ. Implications of the near-planar solution structure of human myeloma dimeric IgA1 for mucosal immunity and IgA nephropathy. J Immunol. 2008;180(2):1008-1018. doi:10.4049/ jimmunol.180.2.1008

67. Lu J, Marjon KD, Mold C, Marnell L, Du Clos TW, Sun P. Pentraxins and IgA share a binding hot-spot on FcalphaRI. Protein Sci. 2014;23(4):378-386. doi:10.1002/pro.2419

68. Xue J, Zhao Q, Zhu L, Zhang W. Deglycosylation of FcalphaR at N58 increases its binding to IgA. Glycobiology. 2010;20 (7):905-915. doi:10.1093/glycob/cwq048

69. Bakema JE, Bakker A, de Haij S, Honing H, Bracke M, Koenderman L. Inside-out regulation of Fc alpha RI (CD89) depends on PP2A. $J$ Immunol. 2008;181(6):4080-4088. doi:10.1038/s41467-017-00294-0

70. Weisbart RH, Kacena A, Schuh A, Golde DW. GM-CSF induces human neutrophil IgA-mediated phagocytosis by an IgA Fc receptor activation mechanism. Nature. 1988;332 (6165):647-648. doi:10.1038/332647a0

71. Bracke M, Dubois GR, Bolt K, et al. Differential effects of the $\mathrm{T}$ helper cell type 2-derived cytokines IL-4 and IL-5 on ligand binding to $\operatorname{IgG}$ and $\operatorname{IgA}$ receptors expressed by human eosinophils. J Immunol. 1997;159(3):1459-1465.

72. Morton HC, van den Herik-oudijk IE, Vossebeld P, et al. Functional association between the human myeloid immunoglobulin A Fc receptor (CD89) and FcR gamma chain. Molecular basis for CD89/FcR gamma chain association. $J$ Biol Chem. 1995;270(50):29781-29787. doi:10.1074/jbc.270.50.29781

73. Pfirsch-Maisonnas S, Aloulou M, Xu T, et al. Inhibitory ITAM signaling traps activating receptors with the phosphatase SHP-1 to form polarized "inhibisome" clusters. Sci Signal. 2011;4(169): ra24. doi:10.1126/scisignal.2001309

74. Lang ML, Chen YW, Shen L, et al. IgA Fc receptor (FcalphaR) cross-linking recruits tyrosine kinases, phosphoinositide kinases and serine/threonine kinases to glycolipid rafts. Biochem $J$. 2002;364(Pt 2):517-525. doi:10.1042/bj20011696

75. Gulle H, Samstag A, Eibl MM, Wolf HM. Physical and functional association of Fc alpha R with protein tyrosine kinase Lyn. Blood. 1998;91(2):383-391. doi:10.1182/blood.V91.2.383

76. Mkaddem SB, Murua A, Flament H, et al. Lyn and Fyn function as molecular switches that control immunoreceptors to direct homeostasis or inflammation. Nat Commun. 2017;8(1):246.

77. Getahun A, Cambier JC. Of ITIMs, ITAMs, and ITAMis: revisiting immunoglobulin $\mathrm{Fc}$ receptor signaling. Immunol Rev. 2015;268(1):66-73. doi:10.1111/imr.12336

78. Aleyd E, van Hout MW, Ganzevles SH, et al. IgA enhances NETosis and release of neutrophil extracellular traps by polymorphonuclear cells via Fcalpha receptor I. J Immunol. 2014;192 (5):2374-2383. doi:10.4049/jimmunol.1300261

79. van der Steen L, Tuk CW, Bakema JE, et al. Immunoglobulin A: $\mathrm{Fc}(\mathrm{alpha}) \mathrm{RI}$ interactions induce neutrophil migration through release of leukotriene B4. Gastroenterology. 2009;137(6):201829e1-3. doi:10.1053/j.gastro.2009.06.047
80. Vidarsson G, van Der Pol WL, van Den Elsen JM, et al. Activity of human IgG and IgA subclasses in immune defense against neisseria meningitidis serogroup B. J Immunol. 2001;166 (10):6250-6256. doi:10.4049/jimmunol.166.10.6250

81. Geissmann F, Launay P, Pasquier B, et al. A subset of human dendritic cells expresses IgA Fc receptor (CD89), which mediates internalization and activation upon cross-linking by IgA complexes. J Immunol. 2001;166(1):346-352. doi:10.4049/ jimmunol.166.1.346

82. Chen YW, Lang ML, Wade WF. Protein kinase C-alpha and -delta are required for FcalphaR (CD89) trafficking to MHC class II compartments and FcalphaR-mediated antigen presentation. Traffic. 2004;5(8):577-594. doi:10.1111/j.1600-0854.2004.00202.x

83. Pasquier B, Lepelletier Y, Baude C, Hermine O, Monteiro RC. Differential expression and function of IgA receptors (CD89 and CD71) during maturation of dendritic cells. J Leukoc Biol. 2004;76(6):1134-1141. doi:10.1189/jlb.0204101

84. Fayette J, Dubois B, Vandenabeele S, et al. Human dendritic cells skew isotype switching of CD40-activated naive B cells towards IgA1 and IgA2. J Exp Med. 1997;185(11):1909-1918. doi:10.1084/jem.185.11.1909

85. Baumann J, Park CG, Mantis NJ. Recognition of secretory IgA by DC-SIGN: implications for immune surveillance in the intestine. Immunol Lett. 2010;131(1):59-66. doi:10.1016/j.imlet.2010.03.005

86. Corthesy B. Multi-faceted functions of secretory IgA at mucosal surfaces. Front Immunol. 2013;4:185. doi:10.3389/ fimmu.2013.00185

87. Rogier EW, Frantz AL, Bruno ME, Kaetzel CS. Secretory IgA is concentrated in the outer layer of colonic mucus along with gut bacteria. Pathogens. 2014;3(2):390-403. doi:10.3390/ pathogens 3020390

88. Mantis NJ, Rol N, Corthesy B. Secretory IgA's complex roles in immunity and mucosal homeostasis in the gut. Mucosal Immunol. 2011;4(6):603-611. doi:10.1038/mi.2011.41

89. Yan H, Lamm ME, Bjorling E, Huang YT. Multiple functions of immunoglobulin A in mucosal defense against viruses: an in vitro measles virus model. J Virol. 2002;76(21):10972-10979. doi:10.1128/JVI.76.21.10972-10979.2002

90. Mazanec MB, Kaetzel CS, Lamm ME, Fletcher D, Nedrud JG. Intracellular neutralization of virus by immunoglobulin A antibodies. Proc Natl Acad Sci U S A. 1992;89(15):6901-6905. doi:10.1073/pnas.89.15.6901

91. Mantis NJ, Palaia J, Hessell AJ, et al. Inhibition of HIV-1 infectivity and epithelial cell transfer by human monoclonal IgG and IgA antibodies carrying the b12 V region. J Immunol. 2007;179 (5):3144-3152. doi:10.4049/jimmunol.179.5.3144

92. Wright A, Lamm ME, Huang YT. Excretion of human immunodeficiency virus type 1 through polarized epithelium by immunoglobulin A. J Virol. 2008;82(23):11526-11535. doi:10.1128/ JVI.01111-08

93. Kulkarni V, Ruprecht RM. Mucosal IgA responses: damaged in established HIV infection-yet, effective weapon against HIV transmission. Front Immunol. 2017;8:1581. doi:10.3389/ fimmu.2017.01581

94. Blutt SE, Conner ME. The gastrointestinal frontier: IgA and viruses. Front Immunol. 2013;4:402. doi:10.3389/ fimmu.2013.00402

95. Sutherland DB, Suzuki K, Fagarasan S. Fostering of advanced mutualism with gut microbiota by immunoglobulin A. Immunol Rev. 2016;270(1):20-31. doi:10.1111/imr.12384

96. Kawamoto S, Maruya M, Kato LM, et al. Foxp3(+) T cells regulate immunoglobulin a selection and facilitate diversification of bacterial species responsible for immune homeostasis. Immunity. 2014;41(1):152-165. doi:10.1016/j. immuni.2014.05.016 
97. Wijburg OL, Uren TK, Simpfendorfer K, Johansen FE, Brandtzaeg P, Strugnell RA. Innate secretory antibodies protect against natural salmonella typhimurium infection. $J$ Exp Med. 2006;203(1):21-26. doi:10.1084/jem.20052093

98. Reikvam DH, Derrien M, Islam R, et al. Epithelial-microbial crosstalk in polymeric Ig receptor deficient mice. Eur J Immunol. 2012;42(11):2959-2970. doi:10.1002/eji.201242543

99. Catanzaro JR, Strauss JD, Bielecka A, et al. IgA-deficient humans exhibit gut microbiota dysbiosis despite secretion of compensatory IgM. Sci Rep. 2019;9(1):13574. doi:10.1038/s41598-01949923-2

100. Kabbert J, Benckert J, Rollenske T, et al. High microbiota reactivity of adult human intestinal IgA requires somatic mutations. J Exp Med. 2020;217(11):11. doi:10.1084/jem.20200275

101. Bunker JJ, Erickson SA, Flynn TM, et al. Natural polyreactive IgA antibodies coat the intestinal microbiota. Science. 2017;358 (6361):6361. doi:10.1126/science.aan6619

102. Nakajima A, Vogelzang A, Maruya M, et al. IgA regulates the composition and metabolic function of gut microbiota by promoting symbiosis between bacteria. J Exp Med. 2018;215 (8):2019-2034. doi:10.1084/jem.20180427

103. Wilmore JR, Gaudette BT, Gomez Atria D, et al. Commensal microbes induce serum IgA responses that protect against polymicrobial sepsis. Cell Host Microbe. 2018;23(3):302-11 e3. doi:10.1016/j.chom.2018.01.005

104. Kozakova H, Schwarzer M, Tuckova L, et al. Colonization of germ-free mice with a mixture of three lactobacillus strains enhances the integrity of gut mucosa and ameliorates allergic sensitization. Cell Mol Immunol. 2016;13(2):251-262. doi:10.1038/cmi.2015.09

105. Matysiak-Budnik T, Moura IC, Arcos-Fajardo M, et al. Secretory IgA mediates retrotranscytosis of intact gliadin peptides via the transferrin receptor in celiac disease. J Exp Med. 2008;205 (1):143-154. doi:10.1084/jem.20071204

106. Rochereau N, Drocourt D, Perouzel E, et al. Dectin-1 is essential for reverse transcytosis of glycosylated SIgA-antigen complexes by intestinal M cells. PLoS Biol. 2013;11(9):e1001658. doi:10.1371/journal.pbio. 1001658

107. Alpan O, Rudomen G, Matzinger P. The role of dendritic cells, $\mathrm{B}$ cells, and $\mathrm{M}$ cells in gut-oriented immune responses. J Immunol. 2001;166(8):4843-4852. doi:10.4049/jimmunol.166.8.4843

108. Van Epps DE, Williams RC Jr. Suppression of leukocyte chemotaxis by human IgA myeloma components. J Exp Med. 1976;144 (5):1227-1242. doi:10.1084/jem.144.5.1227

109. Wilton JM. Suppression by IgA of IgG-mediated phagocytosis by human polymorphonuclear leucocytes. Clin Exp Immunol. 1978;34(3):423-428

110. Wolf HM, Fischer MB, Puhringer H, Samstag A, Vogel E, Eibl MM. Human serum IgA downregulates the release of inflammatory cytokines (tumor necrosis factor-alpha, interleukin-6) in human monocytes. Blood. 1994;83(5):1278-1288. doi:10.1182/ blood.V83.5.1278.1278

111. Olas K, Butterweck H, Teschner W, Schwarz HP, Reipert B. Immunomodulatory properties of human serum immunoglobulin A: anti-inflammatory and pro-inflammatory activities in human monocytes and peripheral blood mononuclear cells. Clin Exp Immunol. 2005;140(3):478-490. doi:10.1111/j.13652249.2005.02779.x

112. Rogier EW, Frantz AL, Bruno ME, et al. Secretory antibodies in breast milk promote long-term intestinal homeostasis by regulating the gut microbiota and host gene expression. Proc Natl Acad Sci U S A. 2014;111(8):3074-3079. doi:10.1073/ pnas.1315792111

113. Hurley WL, Theil PK. Perspectives on immunoglobulins in colostrum and milk. Nutrients. 2011;3(4):442-474. doi:10.3390/ nu3040442
114. Gopalakrishna KP, Hand TW. Influence of maternal milk on the neonatal intestinal microbiome. Nutrients. 2020;12(3):823. doi:10.3390/nu12030823

115. Jones G, Steketee RW, Black RE, Bhutta ZA, Morris SS. Bellagio child survival study G. How many child deaths can we prevent this year? Lancet. 2003;362(9377):65-71. doi:10.1016/S01406736(03)13811-1

116. Gopalakrishna KP, Macadangdang BR, Rogers MB, et al. Maternal IgA protects against the development of necrotizing enterocolitis in preterm infants. Nat Med. 2019;25 (7):1110-1115. doi:10.1038/s41591-019-0480-9

117. Rognum TO, Thrane S, Stoltenberg L, Vege A, Brandtzaeg P. Development of intestinal mucosal immunity in fetal life and the first postnatal months. Pediatr Res. 1992;32(2):145-149. doi:10.1203/00006450-199208000-00003

118. Brandtzaeg P, Nilssen DE, Rognum TO, Thrane PS. Ontogeny of the mucosal immune system and IgA deficiency. Gastroenterol Clin North Am. 1991;20(3):397-439.

119. Blanco E, Perez-Andres M, Arriba-Mendez S, et al. Ageassociated distribution of normal B-cell and plasma cell subsets in peripheral blood. J Allergy Clin Immunol. 2018;141(6):220819 e16. doi:10.1016/j.jaci.2018.02.017

120. Miller EM, McConnell DS. Milk immunity and reproductive status among Ariaal women of northern Kenya. Ann Hum Biol. 2015;42(1):76-83. doi:10.3109/03014460.2014.941398

121. Fujita M, Wander K, Paredes Ruvalcaba N, Brindle E. Human milk SIgA antibody in relation to maternal nutrition and infant vulnerability in northern Kenya. Evol Med Public Health. 2019;2019(1):201-211. doi:10.1093/emph/eoz030

122. Gorter A, Hiemstra PS, Leijh PC, et al. IgA- and secretory IgA-opsonized S. aureus induce a respiratory burst and phagocytosis by polymorphonuclear leucocytes. Immunology. 1987;61 (3):303-309.

123. Duc M, Johansen F-E, Corthesy B. Antigen binding to secretory immunoglobulin A results in decreased sensitivity to intestinal proteases and increased binding to cellular $\mathrm{Fc}$ receptors. J Biol Chem. 2010;285(2):953-960. doi:10.1074/ jbc.M109.059220

124. Trend S, de Jong E, Lloyd ML, et al. Leukocyte populations in human preterm and term breast milk identified by multicolour flow cytometry. PLoS One. 2015;10(8):e0135580. doi:10.1371/ journal.pone. 0135580

125. Honorio-Franca AC, Launay P, Carneiro-Sampaio MM, Monteiro RC. Colostral neutrophils express Fc alpha receptors (CD89) lacking gamma chain association and mediate noninflammatory properties of secretory IgA. J Leukoc Biol. 2001;69 (2):289-296.

126. Zimmermann N, Thormann V, Hu B, et al. Human isotype-dependent inhibitory antibody responses against Mycobacterium tuberculosis. EMBO Mol Med. 2016;8 (11):1325-1339. doi:10.15252/emmm. 201606330

127. Magri G, Cerutti A. IgA summons IgG to take a hit at HIV-1. Cell Host Microbe. 2020;27(6):854-856. doi:10.1016/j. chom.2020.05.017

128. Chao YX, Rotzschke O, Tan EK. The role of IgA in COVID-19. Brain Behav Immun. 2020;87:182-183. doi:10.1016/j. bbi.2020.05.057

129. Riley RL, Mills CC, Nyka W, et al. Aerial dissemination of pulmonary tuberculosis. A two-year study of contagion in a tuberculosis ward. 1959. Am J Epidemiol. 1995;142(1):3-14. doi:10.1093/oxfordjournals.aje.a117542

130. Bijlsma MW, Bekker V, Brouwer MC, Spanjaard L, van de Beek D, van der Ende A. Epidemiology of invasive meningococcal disease in the Netherlands, 1960-2012: an analysis of national surveillance data. Lancet Infect Dis. 2014;14(9):805-812. doi:10.1016/S1473-3099(14)70806-0 
131. Zhang Q, Finn A. Mucosal immunology of vaccines against pathogenic nasopharyngeal bacteria. J Clin Pathol. 2004;57 (10):1015-1021. doi:10.1136/jcp.2004.016253

132. Tuomanen EI, Austrian R, Masure HR. Pathogenesis of pneumococcal infection. $N$ Engl J Med. 1995;332(19):1280-1284. doi:10.1056/NEJM199505113321907

133. Musher DM, Groover JE, Reichler MR, et al. Emergence of antibody to capsular polysaccharides of Streptococcus pneumoniae during outbreaks of pneumonia: association with nasopharyngeal colonization. Clin Infect Dis. 1997;24(3):441-446. doi:10.1093/clinids/24.3.441

134. Wu M, Zhao H, Li M, Yue Y, Xiong S, Xu W. Intranasal vaccination with mannosylated chitosan formulated DNA vaccine enables robust $\operatorname{IgA}$ and cellular response induction in the lungs of mice and improves protection against pulmonary mycobacterial challenge. Front Cell Infect Microbiol. 2017;7:445. doi:10.3389/ fcimb.2017.00445

135. Ferreira DM, Darrieux M, Silva DA, et al. Characterization of protective mucosal and systemic immune responses elicited by pneumococcal surface protein PspA and PspC nasal vaccines against a respiratory pneumococcal challenge in mice. Clin Vaccine Immunol. 2009;16(5):636-645. doi:10.1128/CVI.00395-08

136. Jia M, Liberatore RA, Guo Y, et al. VSV-displayed HIV-1 envelope identifies broadly neutralizing antibodies class-switched to IgG and IgA. Cell Host Microbe. 2020;27(6):963-75 e5. doi:10.1016/j.chom.2020.03.024

137. Watkins JD, Sholukh AM, Mukhtar MM, et al. Anti-HIV IgA isotypes: differential virion capture and inhibition of transcytosis are linked to prevention of mucosal R5 SHIV transmission. AIDS. 2013;27(9):F13-20. doi:10.1097/ QAD.0b013e328360eac6

138. Sholukh AM, Watkins JD, Vyas HK, et al. Defense-in-depth by mucosally administered anti-HIV dimeric IgA2 and systemic IgG1 mAbs: complete protection of rhesus monkeys from mucosal SHIV challenge. Vaccine. 2015;33(17):2086-2095. doi:10.1016/j.vaccine.2015.02.020

139. Johansen K, Svensson L. Neutralization of rotavirus and recognition of immunologically important epitopes on VP4 and VP7 by human IgA. Arch Virol. 1997;142(7):1491-1498. doi:10.1007/ s007050050175

140. To TL, Ward LA, Yuan L, Saif LJ. Serum and intestinal isotype antibody responses and correlates of protective immunity to human rotavirus in a gnotobiotic pig model of disease. $J$ Gen Virol. 1998;79(Pt 11):2661-2672.

141. Crawford SE, Patel DG, Cheng E, et al. Rotavirus viremia and extraintestinal viral infection in the neonatal rat model. $J$ Virol. 2006;80(10):4820-4832. doi:10.1128/JVI.80.10.4820-4832.2006

142. Feng N, Burns JW, Bracy L, Greenberg HB. Comparison of mucosal and systemic humoral immune responses and subsequent protection in mice orally inoculated with a homologous or a heterologous rotavirus. $J$ Virol. 1994;68(12):7766-7773. doi:10.1128/JVI.68.12.7766-7773.1994

143. Iyer AS, Jones FK, Nodoushani A, et al. Persistence and decay of human antibody responses to the receptor binding domain of SARS-CoV-2 spike protein in COVID-19 patients. Sci Immunol. 2020;5(52):52. doi:10.1126/sciimmunol.abe0367

144. Kowitdamrong E, Puthanakit T, Jantarabenjakul W, et al. Antibody responses to SARS-CoV-2 in patients with differing severities of coronavirus disease 2019. PLoS One. 2020;15(10): e0240502. doi:10.1371/journal.pone.0240502

145. Sterlin D, Mathian A, Miyara M, et al. IgA dominates the early neutralizing antibody response to SARS-CoV-2. medRxiv. 2020;2020.06.10.20126532.

146. Xue M, Zhang T, Hu H, et al. Predictive effects of IgA and IgG combination to assess pulmonary exudation progression in COVID-19 patients. J Med Virol. 2020. doi:10.1002/jmv.26437
147. Ejemel M, Li Q, Hou S, et al. A cross-reactive human IgA monoclonal antibody blocks SARS-CoV-2 spike-ACE2 interaction. Nat Commun. 2020;11(1):4198. doi:10.1038/s41467020-18058-8

148. Hasan Ali O, Bomze D, Risch L, et al. Severe COVID-19 is associated with elevated serum $\operatorname{IgA}$ and antiphospholipid IgA-antibodies. Clin Infect Dis. 2020. doi:10.1093/cid/ciaa1496

149. Yu HQ, Sun BQ, Fang ZF, et al. Distinct features of SARS-CoV2-specific IgA response in COVID-19 patients. Eur Respir J. 2020;56(2):2001526. doi:10.1183/13993003.01526-2020

150. Fourati S, Hue S, Pawlotsky JM, Mekontso-Dessap A, de Prost N. SARS-CoV-2 viral loads and serum $\mathrm{IgA} / \mathrm{IgG}$ immune responses in critically ill COVID-19 patients. Intensive Care Med. 2020;46 (9):1781-1783. doi:10.1007/s00134-020-06157-5

151. Casadevall A, Pirofski LA. The convalescent sera option for containing COVID-19. J Clin Invest. 2020;130(4):1545-1548. doi:10.1172/JCI138003

152. Li L, Zhang W, Hu Y, et al. Effect of convalescent plasma therapy on time to clinical improvement in patients with severe and life-threatening COVID-19: a randomized clinical trial. JAMA. 2020;324(5):460-470. doi:10.1001/jama.2020.10044

153. Liu STH, Lin HM, Baine I, et al. Convalescent plasma treatment of severe COVID-19: a propensity score-matched control study. Nat Med. 2020;26(11):1708-1713. doi:10.1038/s41591-0201088-9

154. Ye M, Fu D, Ren Y, et al. Treatment with convalescent plasma for COVID-19 patients in Wuhan, China. J Med Virol. 2020;92 (10):1890-1901. doi:10.1002/jmv.25882

155. Salazar E, Perez KK, Ashraf M, et al. Treatment of coronavirus disease 2019 (COVID-19) patients with convalescent plasma. Am J Pathol. 2020;190(8):1680-1690. doi:10.1016/j.ajpath.2020.05.014

156. Perotti C, Baldanti F, Bruno R, et al. Mortality reduction in 46 severe Covid-19 patients treated with hyperimmune plasma. A proof of concept single arm multicenter trial. Haematologica. 2020. doi:10.3324/haematol.2020.261784

157. Nauseef WM, Borregaard N. Neutrophils at work. Nat Immunol. 2014;15(7):602-611. doi:10.1038/ni.2921

158. Hellwig SM, van Spriel AB, Schellekens JF, Mooi FR, van de Winkel JG. Immunoglobulin A-mediated protection against bordetella pertussis infection. Infect Immun. 2001;69(8):4846-4850. doi:10.1128/IAI.69.8.4846-4850.2001

159. van Spriel AB, van den Herik-oudijk IE, van Sorge NM, Vile HA, van Strijp JA, van de Winkel J. Effective phagocytosis and killing of Candida albicans via targeting Fc $\gamma$ RI (CD64) or Fc $\alpha$ RI (CD89) on neutrophils. J Infect Dis. 1999;179(3):661-669. doi:10.1086/ 314643

160. van der Pol W, Vidarsson G, Vile HA, van de Winkel JG, Rodriguez ME. Pneumococcal capsular polysaccharide-specific IgA triggers efficient neutrophil effector functions via FcalphaRI (CD89). J Infect Dis. 2000;182(4):1139-1145. doi:10.1086/ 315825

161. Kobayashi T, Yamamoto K, Sugita N, et al. Effective in vitro clearance ofPorphyromonas gingivalis by $\mathrm{Fc} \alpha$ receptor I (CD89) on gingival crevicular neutrophils. Infect Immun. 2001;69 (5):2935-2942. doi:10.1128/IAI.69.5.2935-2942.2001

162. Shin EH, Lee HY, Bae YS. Leukotriene B4 stimulates human monocyte-derived dendritic cell chemotaxis. Biochem Biophys Res Commun. 2006;348(2):606-611. doi:10.1016/j.bbrc.2006.07.084

163. Subramanian BC, Majumdar R, Parent CA. The role of the LTB4-BLT1 axis in chemotactic gradient sensing and directed leukocyte migration. Semin Immunol. 2017;33:16-29. doi:10.1016/j.smim.2017.07.002

164. Patry C, Sibille Y, Lehuen A, Monteiro RC. Identification of Fc alpha receptor (CD89) isoforms generated by alternative splicing that are differentially expressed between blood monocytes and alveolar macrophages. J Immunol. 1996;156(11):4442-4448. 
165. Lu LL, Chung AW, Rosebrock TR, et al. A functional role for antibodies in tuberculosis. Cell. 2016;167(2):433-43 e14. doi:10.1016/j.cell.2016.08.072

166. Legesse M, Ameni G, Medhin G, et al. IgA response to ESAT-6/ CFP-10 and Rv2031 antigens varies in patients with culture-confirmed pulmonary tuberculosis, healthy Mycobacterium tuberculosis-infected and non-infected individuals in a tuberculosis endemic setting, Ethiopia. Scand J Immunol. 2013;78(3):266-274. doi:10.1111/sji.12080

167. de Tymowski C, Heming N, Correia MDT, et al. CD89 is a potent innate receptor for bacteria and mediates host protection from sepsis. Cell Rep. 2019;27(3):762-75 e5. doi:10.1016/j. celrep.2019.03.062

168. Tay MZ, Wiehe K, Pollara J. Antibody-dependent cellular phagocytosis in antiviral immune responses. Front Immunol. 2019;10:332. doi:10.3389/fimmu.2019.00332

169. Ackerman ME, Mikhailova A, Brown EP, et al. Polyfunctional HIV-specific antibody responses are associated with spontaneous HIV control. PLoS Pathog. 2016;12(1):e1005315. doi:10.1371/ journal.ppat. 1005315

170. Duchemin M, Khamassi M, Xu L, Tudor D, Bomsel M. IgA targeting human immunodeficiency virus-1 envelope gp41 triggers antibody-dependent cellular cytotoxicity cross-clade and cooperates with gp41-specific IgG to increase cell lysis. Front Immunol. 2018;9:244. doi:10.3389/fimmu.2018.00244

171. Duchemin M, Tudor D, Cottignies-Calamarte A, Bomsel M. Antibody-dependent cellular phagocytosis of HIV-1-infected cells is efficiently triggered by IgA targeting HIV-1 envelope subunit gp41. Front Immunol. 2020;11:1141. doi:10.3389/ fimmu.2020.01141

172. Ackerman ME, Das J, Pittala S, et al. Route of immunization defines multiple mechanisms of vaccine-mediated protection against SIV. Nat Med. 2018;24(10):1590-1598. doi:10.1038/ s41591-018-0161-0

173. Rerks-Ngarm S, Pitisuttithum P, Nitayaphan S, et al. Vaccination with ALVAC and AIDSVAX to prevent HIV-1 infection in Thailand. N Engl J Med. 2009;361(23):2209-2220. doi:10.1056/ NEJMoa0908492

174. Uren TK, Johansen FE, Wijburg OL, Koentgen F, Brandtzaeg P, Strugnell RA. Role of the polymeric Ig receptor in mucosal B cell homeostasis. J Immunol. 2003;170(5):2531-2539. doi:10.4049/ jimmunol.170.5.2531

175. Hansen IS, Hoepel W, Zaat SAJ, Baeten DLP, den Dunnen J. Serum IgA immune complexes promote proinflammatory cytokine production by human macrophages, monocytes, and kupffer cells through FcalphaRI-TLR cross-talk. J Immunol. 2017;199 (12):4124-4131. doi:10.4049/jimmunol.1700883

176. Hansen IS, Baeten DLP, den Dunnen J. The inflammatory function of human IgA. Cell Mol Life Sci. 2019;76(6):1041-1055. doi:10.1007/s00018-018-2976-8

177. Woof JM. Immunoglobulins and their receptors, and subversion of their protective roles by bacterial pathogens. Biochem Soc Trans. 2016;44(6):1651-1658. doi:10.1042/ BST20160246

178. Fasching CE, Grossman T, Corthesy B, Plaut AG, Weiser JN, Janoff EN. Impact of the molecular form of immunoglobulin A on functional activity in defense against Streptococcus pneumoniae. Infect Immun. 2007;75(4):1801-1810. doi:10.1128/ IAI.01758-06

179. Janoff EN, Rubins JB, Fasching C, et al. Pneumococcal IgA1 protease subverts specific protection by human IgA1. Mucosal Immunol. 2014;7(2):249-256. doi:10.1038/mi.2013.41

180. Lin L, Ayala P, Larson J, et al. The Neisseria type $2 \operatorname{IgA} 1$ protease cleaves LAMP1 and promotes survival of bacteria within epithelial cells. Mol Microbiol. 1997;24(5):1083-1094. doi:10.1046/ j.1365-2958.1997.4191776.x
181. Vidarsson G, Overbeeke N, Stemerding AM, et al. Working mechanism of immunoglobulin A1 (IgA1) protease: cleavage of IgA1 antibody to neisseria meningitidis PorA requires de novo synthesis of IgA1 protease. Infect Immun. 2005;73 (10):6721-6726. doi:10.1128/IAI.73.10.6721-6726.2005

182. Polissi A, Pontiggia A, Feger G, et al. Large-scale identification of virulence genes from Streptococcus pneumoniae. Infect Immun. 1998;66(12):5620-5629. doi:10.1128/IAI.66.12.56205629.1998

183. Pleass RJ, Areschoug T, Lindahl G, Woof JM. Streptococcal IgA-binding proteins bind in the Calpha 2-Calpha 3 interdomain region and inhibit binding of IgA to human CD89. J Biol Chem. 2001;276(11):8197-8204. doi:10.1074/jbc.M009396200

184. Ramsland PA, Willoughby N, Trist HM, et al. Structural basis for evasion of IgA immunity by staphylococcus aureus revealed in the complex of SSL7 with Fc of human IgA1. Proc Natl Acad Sci US A. 2007;104(38):15051-15056. doi:10.1073/pnas.0706028104

185. D'Amico G. Natural history of idiopathic IgA nephropathy and factors predictive of disease outcome. Semin Nephrol. 2020;12 (3):823-896. doi:10.1016/j.semnephrol.2004.01.001

186. McGrogan A, Franssen CF, de Vries CS. The incidence of primary glomerulonephritis worldwide: a systematic review of the literature. Nephrol Dial Transplant. 2011;26(2):414-430. doi:10.1093/ndt/gfq665

187. Novak J, Julian BA, Tomana M, Mestecky J. IgA glycosylation and IgA immune complexes in the pathogenesis of $\operatorname{IgA}$ nephropathy. Semin Nephrol. 2019;10(1):78-87. doi:10.1016/j. semnephrol.2007.10.009

188. Chen A, Yang SS, Lin TJ, Ka SM. IgA nephropathy: clearance kinetics of IgA-containing immune complexes. Semin Immunopathol. 2018;40(6):539-543. doi:10.1007/s00281-0180708-7

189. Gutierrez E, Carvaca-Fontan F, Luzardo L, Morales E, Alonso M, Praga M. A personalized update on IgA nephropathy: a new vision and new future challenges. Nephron. 2020;144 (11):555-571. doi:10.1159/000509997

190. Berthelot L, Papista C, Maciel TT, et al. Transglutaminase is essential for IgA nephropathy development acting through $\operatorname{IgA}$ receptors. J Exp Med. 2012;209(4):793-806. doi:10.1084/ jem.20112005

191. Launay P, Grossetete B, Arcos-Fajardo M, et al. Fcalpha receptor (CD89) mediates the development of immunoglobulin A (IgA) nephropathy (Berger's disease). Evidence for pathogenic soluble receptor-Iga complexes in patients and CD89 transgenic mice. $J$ Exp Med. 2000;191(11):1999-2009. doi:10.1084/jem.191.11.1999

192. Rifai A, Fadden K, Morrison SL, Chintalacharuvu KR. The $\mathrm{N}$-glycans determine the differential blood clearance and hepatic uptake of human immunoglobulin (Ig)A1 and IgA2 isotypes. J Exp Med. 2020;27(6):963-975.e5. doi:10.1084/jem.191.12.2171

193. Xu L, Li B, Huang M, et al. Critical role of kupffer cell CD89 expression in experimental IgA nephropathy. PLoS One. 2016;11 (7):e0159426.

194. Aletaha D, Neogi T, Silman AJ, et al. Rheumatoid arthritis classification criteria: an American college of rheumatology/ European league against rheumatism collaborative initiative. Arthritis Rheum. 2010;62(9):2569-2581. doi:10.1002/art.27584

195. Moeez S, John P, Bhatti A. Anti-citrullinated protein antibodies: role in pathogenesis of RA and potential as a diagnostic tool. Rheumatol Int. 2013;33(7):1669-1673. doi:10.1007/s00296-0122635-6

196. Jonsson T, Arinbjarnarson S, Thorsteinsson J, et al. Raised IgA rheumatoid factor (RF) but not IgM RF or IgG RF is associated with extra-articular manifestations in rheumatoid arthritis. Scand J Rheumatol. 1995;24(6):372-375. doi: $10.3109 / 03009749509095183$ 
197. Bobbio-Pallavicini F, Caporali R, Alpini C, et al. High IgA rheumatoid factor levels are associated with poor clinical response to tumour necrosis factor alpha inhibitors in rheumatoid arthritis. Ann Rheum Dis. 2007;66(3):302-307. doi:10.1136/ ard.2006.060608

198. Nielen MM, van Schaardenburg D, Reesink HW, et al. Specific autoantibodies precede the symptoms of rheumatoid arthritis: a study of serial measurements in blood donors. Arthritis Rheum. 2004;50(2):380-386. doi:10.1002/art.20018

199. Rantapaa-Dahlqvist S, de Jong BA, Berglin E, et al. Antibodies against cyclic citrullinated peptide and IgA rheumatoid factor predict the development of rheumatoid arthritis. Arthritis Rheum. 2003;48(10):2741-2749. doi:10.1002/art.11223

200. Kinslow JD, Blum LK, Deane KD, et al. Elevated IgA plasmablast levels in subjects at risk of developing rheumatoid arthritis. Arthritis Rheumatol. 2016;68(10):2372-2383. doi:10.1002/ art.39771

201. Svard A, Kastbom A, Soderlin MK, Reckner-Olsson A, Skogh T. A comparison between IgG- and IgA-class antibodies to cyclic citrullinated peptides and to modified citrullinated vimentin in early rheumatoid arthritis and very early arthritis. J Rheumatol. 2011;38(7):1265-1272. doi:10.3899/jrheum.101086

202. Kokkonen H, Mullazehi M, Berglin E, et al. Antibodies of IgG, IgA and IgM isotypes against cyclic citrullinated peptide precede the development of rheumatoid arthritis. Arthritis Res Ther. 2011;13(1):R13. doi:10.1186/ar3237

203. Anquetil F, Clavel C, Offer G, Serre G, Sebbag M. IgM and IgA rheumatoid factors purified from rheumatoid arthritis sera boost the Fc receptor- and complement-dependent effector functions of the disease-specific anti-citrullinated protein autoantibodies. J Immunol. 2015;194(8):3664-3674. doi:10.4049/jimmunol.1402334

204. Du L, Wang P, Liu C, Li S, Yue S, Yang Y. Multisystemic manifestations of IgA vasculitis. Clin Rheumatol. 2020. doi:10.1007/s10067-020-05166-5

205. Yang YH, Wang SJ, Chuang YH, Lin YT, Chiang BL. The level of IgA antibodies to human umbilical vein endothelial cells can be enhanced by TNF-alpha treatment in children with Henoch-Schonlein purpura. Clin Exp Immunol. 2002;130 (2):352-357. doi:10.1046/j.1365-2249.2002.01964.x

206. Berthelot L, Jamin A, Viglietti D, et al. Value of biomarkers for predicting immunoglobulin A vasculitis nephritis outcome in an adult prospective cohort. Nephrol Dial Transplant. 2018;33 (9):1579-1590. doi:10.1093/ndt/gfx300

207. Sardy M, Karpati S, Merkl B, Paulsson M, Smyth N. Epidermal transglutaminase (TGase 3) is the autoantigen of dermatitis herpetiformis. J Exp Med. 2002;195(6):747-757. doi:10.1084/ jem.20011299

208. Taylor TB, Schmidt LA, Meyer LJ, Zone JJ. Transglutaminase 3 present in the IgA aggregates in dermatitis herpetiformis skin is enzymatically active and binds soluble fibrinogen. $J$ Invest Dermatol. 2015;135(2):623-625. doi:10.1038/jid.2014.368

209. Davalos D, Akassoglou K. Fibrinogen as a key regulator of inflammation in disease. Semin Immunopathol. 2012;34(1):43-62.

210. Smith AD, Streilein RD, Hall RP 3rd. Neutrophil CD11b, L-selectin and Fc IgA receptors in patients with dermatitis herpetiformis. $\mathrm{Br} J$ Dermatol. 2002;147(6):1109-1117. doi:10.1046/j.1365-2133.2002.05004.x

211. Gornowicz-Porowska J, Seraszek-Jaros A, BowszycDmochowska M, Kaczmarek E, Dmochowski M. Immunoexpression of IgA receptors (CD89, CD71) in dermatitis herpetiformis. Folia Histochem Cytobiol. 2017;55(4):212-220. doi:10.5603/FHC.a2017.0024

212. Russo V, Klein T, Lim DJ, et al. Granzyme B is elevated in autoimmune blistering diseases and cleaves key anchoring proteins of the dermal-epidermal junction. Sci Rep. 2018;8(1):9690. doi:10.1038/s41598-018-28070-0
213. Coppo R, Amore A, Roccatello D. Dietary antigens and primary immunoglobulin A nephropathy. J Am Soc Nephrol. 1992;2(10 Suppl):S173-80.

214. Sitaru C, Zillikens D. Mechanisms of blister induction by autoantibodies. Exp Dermatol. 2005;14(12):861-875. doi:10.1111/j.1600-0625.2005.00367.x

215. van der Steen LP, Bakema JE, Sesarman A, et al. Blocking Fcalpha receptor I on granulocytes prevents tissue damage induced by IgA autoantibodies. $J$ Immunol. 2012;189 (4):1594-1601. doi:10.4049/jimmunol.1101763

216. Park JH, Peyrin-Biroulet L, Eisenhut M, Shin JI. IBD immunopathogenesis: a comprehensive review of inflammatory molecules. Autoimmun Rev. 2017;16(4):416-426. doi:10.1016/j. autrev.2017.02.013

217. Palm NW, de Zoete MR, Cullen TW, et al. Immunoglobulin A coating identifies colitogenic bacteria in inflammatory bowel disease. Cell. 2014;158(5):1000-1010. doi:10.1016/j.cell.2014.08.006

218. van der Waaij LA, Kroese FG, Visser A, et al. Immunoglobulin coating of faecal bacteria in inflammatory bowel disease. Eur $J$ Gastroenterol Hepatol. 2004;16(7):669-674. doi:10.1097/01. meg.0000108346.41221.19

219. Mitsuyama K, Niwa M, Takedatsu H, et al. Antibody markers in the diagnosis of inflammatory bowel disease. World $J$ Gastroenterol. 2016;22(3):1304-1310. doi:10.3748/wjg.v22. i3. 1304

220. Rengarajan S, Vivio EE, Parkes M, et al. Dynamic immunoglobulin responses to gut bacteria during inflammatory bowel disease. Gut Microbes. 2020;11(3):405-420. doi:10.1080/ 19490976.2019.1626683

221. Bakema JE, Tuk CW, van Vliet SJ, et al. Antibody-opsonized bacteria evoke an inflammatory dendritic cell phenotype and polyfunctional Th cells by cross-talk between TLRs and FcRs. J Immunol. 2015;194 (4):1856-1866. doi:10.4049/jimmunol.1303126

222. Maloy KJ, Powrie F. Intestinal homeostasis and its breakdown in inflammatory bowel disease. Nature. 2011;474(7351):298-306. doi:10.1038/nature10208

223. Miquel-Clopes A, Bentley EG, Stewart JP, Carding SR. Mucosal vaccines and technology. Clin Exp Immunol. 2019;196 (2):205-214. doi:10.1111/cei.13285

224. Vela Ramirez JE, Sharpe LA, Peppas NA. Current state and challenges in developing oral vaccines. Adv Drug Deliv Rev. 2017;114:116-131. doi:10.1016/j.addr.2017.04.008

225. Thakur A, Rodriguez-Rodriguez C, Saatchi K, et al. Dual-isotope SPECT/CT imaging of the tuberculosis subunit vaccine H56/ CAF01: induction of strong systemic and mucosal $\operatorname{IgA}$ and T-cell responses in mice upon subcutaneous prime and intrapulmonary boost immunization. Front Immunol. 2018;9:2825. doi:10.3389/fimmu.2018.02825

226. Balu S, Reljic R, Lewis MJ, et al. A novel human IgA monoclonal antibody protects against tuberculosis. $J$ Immunol. 2011;186(5):3113-3119. doi:10.4049/jimmunol.1003189

227. Williams A, Reljic R, Naylor I, et al. Passive protection with immunoglobulin A antibodies against tuberculous early infection of the lungs. Immunology. 2004;111(3):328-333. doi:10.1111/ j.1365-2567.2004.01809.x

228. Casadevall A. Antibodies to mycobacterium tuberculosis. $N$ Engl $J$ Med. 2017;376(3):283-285. doi:10.1056/NEJMcibr1613268

229. Briles DE, Ades E, Paton JC, et al. Intranasal immunization of mice with a mixture of the pneumococcal proteins PsaA and PspA is highly protective against nasopharyngeal carriage of Streptococcus pneumoniae. Infect Immun. 2000;68(2):796-800. doi:10.1128/IAI.68.2.796-800.2000

230. Fukuyama Y, King JD, Kataoka K, Kobayashi R, Gilbert RS, Oishi K. Secretory-IgA antibodies play an important role in the immunity to Streptococcus pneumoniae. J Immunol. 2010;185 (3):1755-1762. doi:10.4049/jimmunol.1000831 
231. Parker EP, Molodecky NA, Pons-Salort M, O'Reilly KM, Grassly NC. Impact of inactivated poliovirus vaccine on mucosal immunity: implications for the polio eradication endgame. Expert Rev Vaccines. 2015;14(8):1113-1123. doi:10.1586/ 14760584.2015 .1052800

232. Patel M, Glass RI, Jiang B, Santosham M, Lopman B, Parashar U. A systematic review of anti-rotavirus serum IgA antibody titer as a potential correlate of rotavirus vaccine efficacy. J Infect Dis. 2013;208(2):284-294. doi:10.1093/infdis/ jit166

233. Blutt SE, Miller AD, Salmon SL, Metzger DW, Conner ME. IgA is important for clearance and critical for protection from rotavirus infection. Mucosal Immunol. 2012;5(6):712-719. doi:10.1038/mi.2012.51

234. McNeal MM, Stone SC, Basu M, et al. Protection against rotavirus shedding after intranasal immunization of mice with a chimeric VP6 protein does not require intestinal IgA. Virology. 2006;346(2):338-347. doi:10.1016/j.virol.2005.11.016

235. McNeal MM, Ward RL. Long-term production of rotavirus antibody and protection against reinfection following a single infection of neonatal mice with murine rotavirus. Virology. 1995;211 (2):474-480. doi:10.1006/viro.1995.1429

236. Buisman AM, Abbink F, Schepp RM, Sonsma JA, Herremans T, Kimman TG. Preexisting poliovirus-specific IgA in the circulation correlates with protection against virus excretion in the elderly. J Infect Dis. 2008;197(5):698-706. doi:10.1086/527487

237. Renegar KB, Small PA Jr., Boykins LG, Wright PF. Role of IgA versus $\operatorname{IgG}$ in the control of influenza viral infection in the murine respiratory tract. $J$ Immunol. 2004;173(3):1978-1986. doi:10.4049/jimmunol.173.3.1978

238. Tamura S, Funato H, Hirabayashi $\mathrm{Y}$, et al. Cross-protection against influenza A virus infection by passively transferred respiratory tract IgA antibodies to different hemagglutinin molecules. Eur J Immunol. 1991;21(6):1337-1344. doi:10.1002/ eji. 1830210602

239. Hutchings AB, Helander A, Silvey KJ, et al. Secretory immunoglobulin A antibodies against the sigmal outer capsid protein of reovirus type 1 Lang prevent infection of mouse Peyer's patches. J Virol. 2004;78(2):947-957. doi:10.1128/JVI.78.2.947-957.2004

240. Boyaka PN. Inducing mucosal IgA: a challenge for vaccine adjuvants and delivery systems. $J$ Immunol. 2017;199(1):9-16. doi:10.4049/jimmunol.1601775

241. Sterlin D, Gorochov G. When therapeutic IgA antibodies might come of age. Pharmacology. 2020;1-11. doi:10.1159/000510251

242. Heemskerk N, van Egmond M. Monoclonal antibody-mediated killing of tumour cells by neutrophils. Eur J Clin Invest. 2018;48 (Suppl 2):e12962. doi:10.1111/eci.12962

243. Lohse S, Loew S, Kretschmer A, Jansen JHM, Meyer S, Ten Broeke T. Effector mechanisms of IgA antibodies against CD20 include recruitment of myeloid cells for antibody-dependent cell-mediated cytotoxicity and complement-dependent cytotoxicity. Br J Haematol. 2018;181(3):413-417. doi:10.1111/ bjh. 14624

244. Dechant M, Valerius T. IgA antibodies for cancer therapy. Crit Rev Oncol Hematol. 2001;39(1-2):69-77. doi:10.1016/S10408428(01)00105-6

245. Valerius T, Stockmeyer B, van Spriel AB, et al. FcalphaRI (CD89) as a novel trigger molecule for bispecific antibody therapy. Blood. 1997;90(11):4485-4492. doi:10.1182/blood. V90.11.4485

246. Bakema JE, van Egmond M. Immunoglobulin A: a next generation of therapeutic antibodies? MAbs. 2011;3(4):352-361. doi:10.4161/mabs.3.4.16092
247. Boross P, Lohse S, Nederend M, et al. IgA EGFR antibodies mediate tumour killing in vivo. EMBO Mol Med. 2013;5 (8):1213-1226. doi:10.1002/emmm.201201929

248. Meyer S, Nederend M, Jansen JH, et al. Improved in vivo anti-tumor effects of IgA-Her2 antibodies through half-life extension and serum exposure enhancement by FcRn targeting. MAbs. 2016;8(1):87-98.

249. Otten MA, Bakema JE, Tuk CW, et al. Enhanced FcalphaRI-mediated neutrophil migration towards tumour colonies in the presence of endothelial cells. Eur J Immunol. 2012;42 (7):1815-1821.

250. Otten MA, Rudolph E, Dechant M, et al. Immature neutrophils mediate tumor cell killing via IgA but not IgG Fc receptors. $J \quad$ Immunol. 2005;174(9):5472-5480. doi:10.4049/ jimmunol.174.9.5472

251. Bakema JE, Ganzevles SH, Fluitsma DM, et al. Targeting FcalphaRI on polymorphonuclear cells induces tumor cell killing through autophagy. $J$ Immunol. 2011;187(2):726-732. doi:10.4049/jimmunol.1002581

252. Kelton W, Mehta N, Charab W, et al. IgGA: a "cross-isotype" engineered human $\mathrm{Fc}$ antibody domain that displays both IgGlike and IgA-like effector functions. Chem Biol. 2014;21 (12):1603-1609. doi:10.1016/j.chembiol.2014.10.017

253. Borrok MJ, Luheshi NM, Beyaz N, et al. Enhancement of antibody-dependent cell-mediated cytotoxicity by endowing IgG with FcalphaRI (CD89) binding. MAbs. 2015;7(4):743-751. doi:10.1080/19420862.2015.1047570

254. Ben Mkaddem S, Rossato E, Heming N, Monteiro RC. Antiinflammatory role of the IgA Fc receptor (CD89): from autoimmunity to therapeutic perspectives. Autoimmun Rev. 2013;12 (6):666-669. doi:10.1016/j.autrev.2012.10.011

255. Rossato E, Ben Mkaddem S, Kanamaru Y, et al. Reversal of arthritis by human monomeric IgA through the receptor-mediated SH2 domain-containing phosphatase 1 inhibitory pathway. Arthritis Rheumatol. 2015;67(7):1766-1777. doi:10.1002/art.39142

256. Kanamaru Y, Pfirsch S, Aloulou M, et al. Inhibitory ITAM signaling by $\mathrm{Fc}$ alpha RI-FcR gamma chain controls multiple activating responses and prevents renal inflammation. J Immunol. 2008;180(4):2669-2678. doi:10.4049/jimmunol.180.4.2669

257. Watanabe T, Kanamaru Y, Liu C, et al. Negative regulation of inflammatory responses by immunoglobulin A receptor (FcalphaRI) inhibits the development of toll-like receptor-9 signalling-accelerated glomerulonephritis. Clin Exp Immunol. 2011;166(2):235-250. doi:10.1111/j.1365-2249.2011.04452.x

258. Liu C, Kanamaru Y, Watanabe T, et al. Targeted IgA Fc receptor I (FcalphaRI) therapy in the early intervention and treatment of pristane-induced lupus nephritis in mice. Clin Exp Immunol. 2015;181(3):407-416. doi:10.1111/cei.12647

259. Aleyd E, Al M, Tuk CW, van der Laken CJ, van Egmond M. IgA complexes in plasma and synovial fluid of patients with rheumatoid arthritis induce neutrophil extracellular traps via FcalphaRI. $J \quad$ Immunol. 2016;197(12):4552-4559. doi:10.4049/ jimmunol.1502353

260. Heineke MH, van der Steen LPE, Korthouwer RM, et al. Peptide mimetics of immunoglobulin A (IgA) and FcalphaRI block IgA-induced human neutrophil activation and migration. Eur J Immunol. 2017;47(10):1835-1845. doi:10.1002/eji.201646782 


\section{Publish your work in this journal}

ImmunoTargets and Therapy is an international, peer-reviewed open access journal focusing on the immunological basis of diseases, potential targets for immune based therapy and treatment protocols employed to improve patient management. Basic immunology and physiology of the immune system in health, and disease will be also covered. In addition, the journal will focus on the impact of management programs and new therapeutic agents and protocols on patient perspectives such as quality of life, adherence and satisfaction. The manuscript management system is completely online and includes a very quick and fair peer-review system, which is all easy to use. Visit http://www.dovepress.com/testimonials.php to read real quotes from published authors.

Submit your manuscript here: http://www.dovepress.com/immunotargets-and-therapy-journal 